\title{
The measurable impact of a protocoled multimodal physiotherapeutic intervention on the quality of life in patients with non-specific chronic low back pain. A RCT study
}

Robbert Nimal van Amstel ${ }^{1 *}$, Peter Vaes ${ }^{2}$ and Shaun Malone ${ }^{3}$

*Correspondence: Robbert.Van.Amstel@vub.be

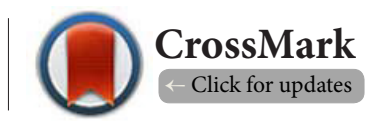

${ }^{1}$ Graduate student (at time of study), University of Brussels, faculty of Rehabilitation science and physical therapy, faculty of Pharmacy and medicine, Brussels, Belgium.

2Professor (at time of study), University of Brussels, faculty of Rehabilitation science and physical therapy, faculty of Pharmacy and medicine, Brussels, Belgium.

${ }^{3}$ Senior Lecturer, Assistant Professor (at time of study), University of Brussels, faculty of Rehabilitation science and physical therapy, faculty of Pharmacy and medicine, Brussels, Belgium.

\begin{abstract}
Study design: One-way, mixed, real experimental RCT study.

Background: A multimodal physiotherapeutic approach to treat non-specific (NSP) Chronic Low Back Pain (CLBP), may affect the quality of life (QoL), pain intensity (PI) and active range of motion (AROM).

The 4 X T method by orthopaedic disorder $($ (4MTOR () is a decision tree to guide the physical therapist to treat NSP-CLBP.

Objectives: To investigate the measureable impact on the QoL, PI and the AROM in patients with NSPCLBP, after physiotherapeutic back rehabilitation care according to the $4 \mathrm{MTOR} \AA$, twice a week during a 6 weeks period.

Methods: This was a RCT, where the experimental group (EGR) received the 4MTOR® compared to an control group (CGR) who received exercise therapy with sham application. The subjects were randomly assigned to one of the two groups. Both groups received physiotherapeutic intervention twice a week for a period of six weeks.

Results: The QoL in the EGR significantly improved on the EQ-5D-index p=0.001. The QoL measured with the EQ-VAS, did significantly improve in both groups $\mathrm{p}<0.001$. However, only a clinically important change was found for the EGR (WO $=59.72 \pm$ SD15.43 to $\mathrm{W} 7=78.63 \pm \mathrm{SD} 17.14)$. The flexion AROM increased significantly $(\mathrm{p}<0.005)$ in the EGR $(\mathrm{W} 0=87.53 \pm \mathrm{SD} 20.45$, W3 $=96.29 \pm \mathrm{SD} 16.34$, W7 $=$ 98.28 $\pm \mathrm{SD} 17.01)$. A significant $(\mathrm{p}<0.01)$ change was also seen for the extension AROM in the EGR $(\mathrm{Wo}=$ $19.36 \pm \mathrm{SD} 9.27, \mathrm{~W} 3=22.25 \pm \mathrm{SD} 5.99, \mathrm{~W} 7=25.55 \pm \mathrm{SD} 7.30)$. The PI reduced only significantly in the EGR during active flexion $(\mathrm{p}<0.001)$. The extension PI did not significantly decrease in both groups, however, a clinically important change was found in the EGR.
\end{abstract}

Conclusion: The positive effects of the $4 \mathrm{MTOR} \AA$ on the Qol, PI and AROM in NSP-CLBP exceeded the effect of exercise therapy with sham application. Further research is required.

Keywords: Low back/lumbar spine, Multimodal Physical therapy interventions, Quality of life, Range of Motion, Pain. Chronic complaints

(C) 2018 Amstel et al; licensee Herbert Publications Ltd. This is an Open Access article distributed under the terms of Creative Commons Attribution License (http://creativecommons.org/licenses/by/3.0). This permits unrestricted use, distribution, and reproduction in any medium, provided the original work is properly cited. 
Amstel et al, Physical Therapy and Rehabilitation 2018,

http://www.hoajonline.com/journals/pdf/2055-2386-5-2.pdf

doi: 10.7243/2055-2386-5-2

\section{Introduction chronic low back pain}

Low back pain (LBP) is a common back complaint and is $8^{\text {th }}$ in the ranking of Disability Adjusted Life Years (DALYs) [36]. In 2015, The Netherlands estimates, 1,982,300 people with diagnosis of neck and back complaints: 832,700 men and 1,149,600 women [37]. The RIVM reports that low back pain (LBP) is most common in musculoskeletal disorder, with a prevalence rate of $43.9 \%$ and a point of prevalence $26,9 \%$, $21.2 \%$ of the LBP were chronic low back complaints [37]. Over $80 \%$ of low back pain is constantly present or consists of recurrent pain. Apparently, according to this report, $20.8 \%$ of adults have chronic low back pain [65]. Mobility of the spine is expressed in Range of Motion (ROM), which is measured during active trunk flexion and extension. The cause of LBP in non-specific chronic low back pain (NSP-CLBP) patients is unknown. Systematic review shows that the lumbar ROM is reduced in patients with low back pain [42]. However, a considerable variability was measured, this may be possible by using different measuring instruments, measurement method and margin of error, but also because LBP can come without ROM reduction [76]. The reduced ROM may adversely affect quality of life (QoL) [31]. We speak of chronicity if this statement is exclusively based on the duration of symptoms of low back pain. Continuous LBP episodes longer than 12 weeks called CLBP [37]. The first episode of low back pain usually occur in people between the age of 22 and 55 years. The LBP can be classified by duration; acute (0-6 weeks), subacute (7-12 weeks) and chronic (12> weeks) [73]. Several studies have investigated the effect of using a multimodal physiotherapeutic intervention the QoL, pain intensity (PI) and active ROM (AROM) in NSP-CLBP patients $[\mathbf{2 0 - 2 2 , 2 4 , 4 0 , 5 9 , 8 1 ] . ~ F r o m ~ t h e s e ~ s t u d i e s , ~ i t ~ i s ~ a p p a r e n t ~ t h a t ~ t h e ~}$ use of a multimodal physiotherapeutic approach combining various physiotherapeutic interventions in NSP-CLBP patients can positively affect the QoL, PI and ROM. The organized multimodal intervention according to the $4 \times \mathrm{T}$ method at orthopaedic rehabilitation $(4$ MTOR () ), is a decision tree as main goal to guide the therapist in choosing the best possible intervention and the right location, direction and intensity of

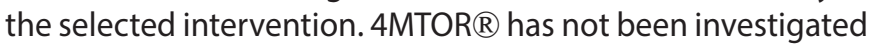
before. This study will compare the $4 M T O R \circledast$ to a exercise program with sham application on the Qol, PI and AROM in NSP-CLBP.

\section{Methods}

\section{Research design \\ Objective}

This study investigated the impact of the physiotherapeutic back rehabilitation care according to the 4 MTOR $\AA$ on NSPCLBP patients. We measured the QoL, PI and the AROM, after a period of 6 weeks twice a week physical therapy. The results in this research were analysed and reported. We hypothesized that the $4 M T O R \circledast$ can positively influence the QoL, PI and the AROM in NSP-CLBP patients. An statistically significant effect was found when a $p$ value $<\alpha=0.05$ was achieved [75].
Primary variable was the QoL, this was measured by using the EQ-5D-3L consisting of an EQ-5D-index and an EQ visual analogue scale (EQ-VAS). The EQ-5D-3L questionnaire was developed by Euroqol Group. Secondary outcome measures were the AROM of the active trunk flexion and trunk extension measured with a bubble inclinometer. Also, the PI was scored by the patient during active flexion and extension by means of the Verbal Rating Scale scaled 0-10 (VRS). The measurements took place during week 0 the baseline measurement (W0), week 3 the intermediate measurement (W3) and finally week 7 the post measurement (W7). All participants were informed for the research and agreed by signing the "informed consent" The research was approved by the Committee of Medical Ethics University Hospital University of Brussels, B.U.N. 143201627110.

\section{Participants}

\section{Inclusion and exclusion criteria}

Participants were included when they met the following criteria: NSP-CLBP from 12 weeks and longer, continuously present (with and without recurrent complaints), Age between

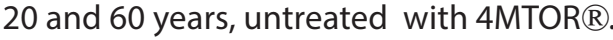

Participants were excluded when they met the following criteria: Radiating disturbing pain beyond the knee, neurological disorder symptoms, overall malaise, spinal cord malignancy, unexplained weight loss, prolonged corticosteroid use, osteoporotic vertebral fracture, spondylitis ankylopoetics, spinal stenosis, rheumatic arthritis, vertebral fracture and severe deformity of the spinal cord.

\section{Recruitment}

\section{Patients recruitment}

The subjects were recruited from orthopaedic hospitals departments in Utrecht the Netherlands. Participants were asked to refer NSP-CLBP patients for this research and by advertisement in an Dutch-language newspaper. Also, NSP-CLBP patients, who applied for physical therapy, were required to participate in this research. A call form was prepared for this purpose. All subjects were asked if they would like to participate in this research. The subjects were authorized to perform medical physiotherapeutic treatment by signing a statement of agreement, as previously stated. Personal data will not be included in this research and are protected by researchers and the Committee of Medical Ethics University Hospital University of Brussels.

Therapist recruitment Experimental intervention group This physiotherapist has been educated and qualified in the KNGF accredited multimodal intervention according to the 4 MTOR $R$. The physiotherapist has at least 2 years of work experience with the use of the 4 MTOR $\AA$ decision tree.

\section{Therapist recruitment SHAM intervention group}

This is a Health Care registered physiotherapist and has at least 3 years work experience and is familiar with the KNGF Low 
Back pain, 2013 guidelines (KNGF_LBP) [74]. Both therapists were informed about their work protocol and have agreed to the implementation of the interventions by signing an informed consent.

\section{Intervention}

\section{Evidence Based Practice EGR}

In the experimental group (EGR), the 4 MTOR $®$ treatment method was used for LBP. This 4 MTOR ${ }^{\circ}$ uses the following steps in a decision tree: T1 Testing (Physiotherapeutic examination), T2 Triggering (Manual Techniques), T3 Taping (Elastic Tape) and T4 Training (medical rehabilitation exercises).

T1: The 4 MTOR $囚$ tests consist of the diagnostic process as described in the KNGF_LBP [74], and mapping the health profile [78]. In addition, a mechanical diagnostic examination is performed. A mechanical approach was previously used in the McKenzie Classification Mechanical Diagnostic Research [50]. In the mechanical diagnostic examination by 4 MTOR $\AA$, the physiotherapist analyses the active movement to find the direction that elicits the most recognizable complaints. According to 4 MTOR ${ }^{\circ}$, the directions for applying the manual interventions and tape should be determined [58]. Noten [58] developed the Dynamic Arthro-Myofascial Translation Test ${ }^{\circledR}$

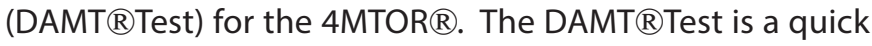
test to investigate and determine the direction of manual interventions and taping. There is no validity and reliability known for this quick test, since it was never tested before. $\mathrm{T} 2$ : The myofascial structures are released to the results of the DAMT ${ }^{\circledR}$ Test, after this that direction was mobilized and impulse mobilization was given on a hypomobile joint, where required. T3: After applying T2 interventions the tape was adjusted. T4: The 4MTOR $®$ uses various fitness exercises and homework assignments in their rehabilitation training plan at NSP-CLBP, which are divided into extension - and flexion based exercises. The training in 4 MTOR ${ }^{\circledR}$ will be within the pain free movement, as well as in the least painful direction. The choice of parameters (frequency, intensity, volume and duration) of the training is adjusted by the physiotherapist and always takes place according to the result of de DAMT®Test. Therefore, initially is chosen for high volume training with low intensity. Gradually, these parameters will change during the physiotherapy care. The endurance training includes cycling on a home trainer, walking on a treadmill , cross-training on a cross trainer of the brand MATRIXTM. Muscle training includes abdominal training on an abdominal crunch machine of the brand MATRIX ${ }^{\mathrm{TM}}$. Back muscle training with Pilates exercises, Brügger back school and on the low-back extension machine of the brand MATRIX ${ }^{\mathrm{TM}}[\mathbf{3 5}, \mathbf{5 7}]$. Finally, spine mobility was trained with Pilates exercises [57].

\section{Evidence Based Practice CGR}

The participants in the CGR received a sham multimodal physiotherapeutic intervention as controlled intervention, in which sham techniques were applied. The interventions consisted of combining sham manual mobilisations, paravertebral elastic taping according to Kaze [32] and Evidence Based Practice Therapy. The protocol in the CGR followed the similar steps: Testing, Taping, Triggering and Training like the 4 MTOR $($. The trunk flexion and extension were tested for treatment (T1), after which a Sham intervention was performed by applying sham elastic tape (ET) and rubbing softly the skin. In this study, similar sham tape technique is used as in the studies of $[2,64]$, wherein the tape was applied paravertebral with $0 \%$ elongation (T2). The shrinkage and lift is the main effect of the ET [32]. Current science cannot support this claim [79]. The sham myofascial release techniques were performed by using sham soft skin rubbing technique. Instead of (impulse) mobilization techniques on the spine, three times ten seconds pressure felt by the subject on the hypomobile vertebra and pain location (T3). In addition, control intervention consisted of an evidence-based practice medical training schedule (EBP-MET) using scientifically proven physiotherapy interventions for LBP $[\mathbf{2 3}, \mathbf{5 3}, \mathbf{7 1}]$. The EBP-MET consists of core stability training, back and abdominal exercises in Matrix ${ }^{\mathrm{TM}}$ fitness machines and muscle stretch exercises. Core stability in back pain is a widely used method in physiotherapy. The aim of core stability training is to recruit effectively the m. multifidus, $\mathrm{m}$. transversus abdominis, pelvic floor and diaphragm. It appears, that the feedforward mechanism of the internal units has been delayed at LBP $[25,26,28]$. Our systematic review has been documented that strength training, in which abdominal and back muscles were trained, including stretching/mobilization of the hamstring, $\mathrm{mm}$ abductors and $\mathrm{m}$. tensor fascia latae has a positive effect on the ROM at (C) LBP [4]. Effective studies of such programs have not made it clear what type of exercises are the best. The KNGF_LBP therefore recommend a varied exercise program that matches the CLBP patient's need, which is time congestion [74].

\section{Randomization and observer}

The Randomization procedure was performed using the list option in the UX Random Number Generator 1.2.4 ${ }^{\circ}$. The simple random allocation method was used to assign the participants to one of the groups. The randomization was performed by an independent person under supervision of the investigator. The randomization process was thereby concealed.

The bubble inclinometer measurement was performed by a trained researcher and was read by a 'blinded' observer who was masked to allocation of subjects.

\section{Outcome measures}

Times pad registration: The measurements were performed on: W0, W3 and finally W7.

\section{Primary outcome measures}

In this study, the participants' QOL was analysed with EQ-5D-3Lindex and EQ-VAS. Each question in EQ-5D-3L-index, included one dimension of QoL: mobility, self-care, daily activities, pain/ 
discomfort \& anxiety/depression. Each dimension has 3 levels (having no problems, having some or moderate problems, being unable to do/having extreme problems) and gets a separate score. The scores can be combined in combination with an assessment of the health status they represent, this rating is expressed in weight or utility. Description of the QoL can be transformed into a QoL assessment by means of a formula. These ratings are based on judgments of the general population of all possible combinations of QoL on the different dimensions (euroqol.org).

The EQ-5D has a good construct validity in chronic complaints and is able to detect changes for the subjective QoL [60]. The study of Soer et al [72], showed that changes in CLBP patients can also be well detected with EQ-5D. In addition, they found a good (criterion) concurrent validity versus multiple gold standards. According to Chapman et al [15], QoL should be measured more often at CLBP, they indicate that EQ-5D is a good method for analysing this. Before EQ-5D-3L was taken, the following question was asked 'Compare your current status with the status of your first measurement of QoL'. The minimal clinically important change $(\mathrm{MCIC})$ for EQ5D-3L-index in CLBP with a 12 week follow- up is between 0.09-0.2866. For EQ-VAS we used the minimum important change (MIC) for VAS 15 points [61]. The use of EQ-5D-3L has been approved and registered by the EuroQol Research Foundation.

\section{Secondary outcome measures}

The AROM: of the lumbar vertebral column was measured with the BASELINE $囚 B U B B L E \circledast I N C L I N O M E T E R$ (Figure 1). The $A R O M$ consisted of active spine flexion and extension. The bubble inclinometer is a very good, reliable and valid measur-

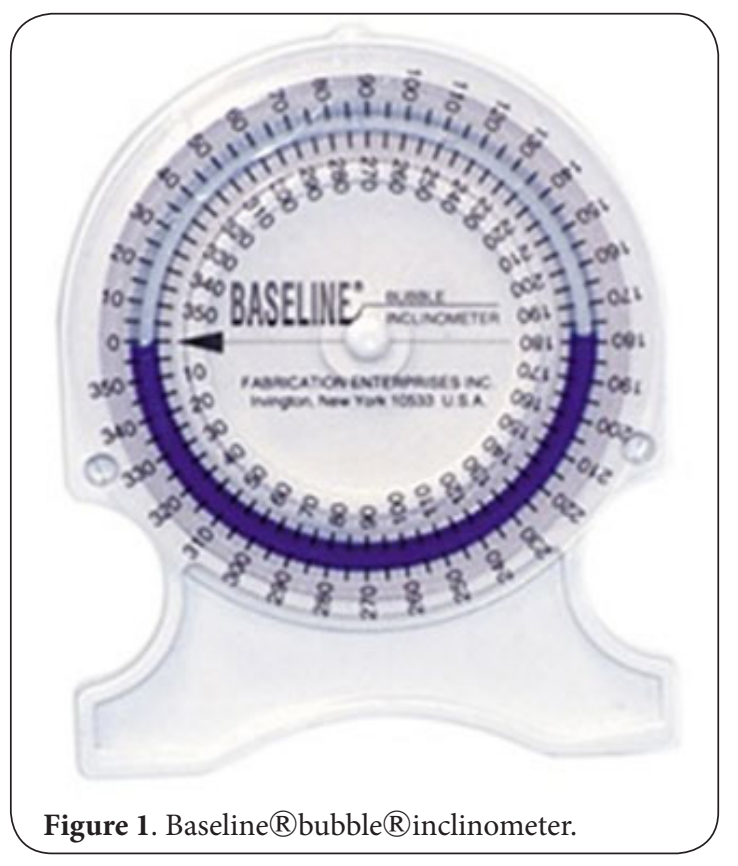

ing instrument, provided this is done by a trained researcher [51]. Three different AROM tests were tested: thoracolumbarpelvic flexion (TLPF), thoracolumbar- pelvic extension (TLPE) and isolated lumbar flexion (ILF) as described in [38]. This measurement was performed in several studies $[69,70,83]$. For clinical relevance, the minimum detectable change (MDC) for the BASELINE ${ }^{B} B U B B L E \circledast I N C L I N O M E T E R$ has been taken into account. The MDC TLPF is $7^{\circ} \leq$ and for TLPE $6^{\circ} \leq$. Finally, the ILF has a MCD of $9^{\circ} \leq[38]$. The detailed description of the operarationalization of the performance is described in section below and the footnotes of the relevant figures.

The VRS: was also measured during spine flexion and extension to observe the participant PI. Studies have shown that a score of $0-10$ must be at least $30 \%$ reduction with a range between 1 to 4.5 on a maximum of 10 points [12]. In this study, a Minimal Important Change (MIC) of 2 points $(4.5<)$ were chosen as described [61]. Before the participant gave a PI number to the active flexion or extension, the VRS scale was shown. Thereafter, the movement was performed as described in the footnotes. After completing the active flexion or extension, the participant gave a VRS score regarding the PI.

\section{Standard procedure inclinometer measurement (Short description)}

Preparation of test: S1/2 and L1/T12 were marked with the dermatological pencil and labelled with tape (Figure 2).

Test performance: The examination was carried out bare footed, the active tests were performed with the head rolling down to the trunk. First, the subjects are actively raising their knees 10 times before adopting their starting position. The inclinometer was placed on the marked point, so the tape was between the inclinometer arcus and was set to $0^{\circ}$. Instruction was given as described in the footnotes, $\mathrm{X}^{\circ}$ was noted by the 'blinded' observer who was masked for allocation of the subjects. The formula was used - as described in Kolber et al [38] . For detail see Figures 3-6.

\section{Statistical analysis}

In this study we used a $\mathrm{p}$ value $<\mathrm{a}=0.05$ to show statistical significance. The outcome variables from the measurements,

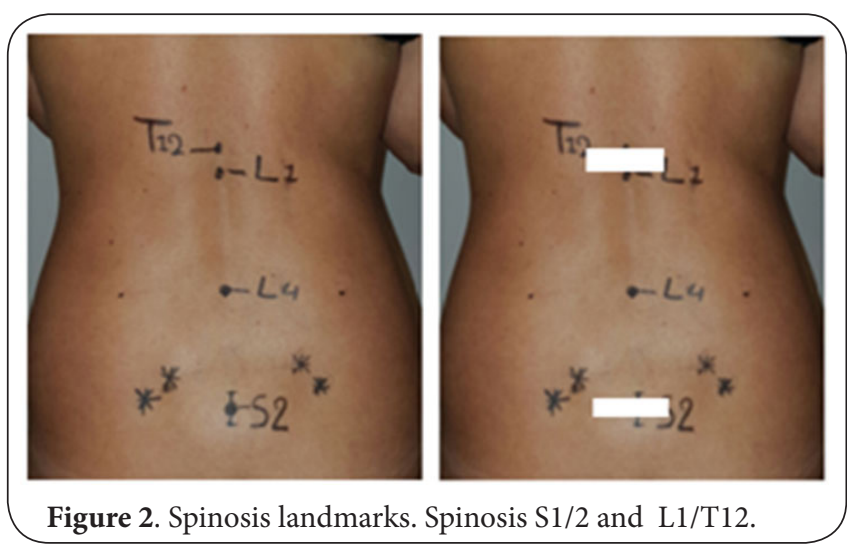



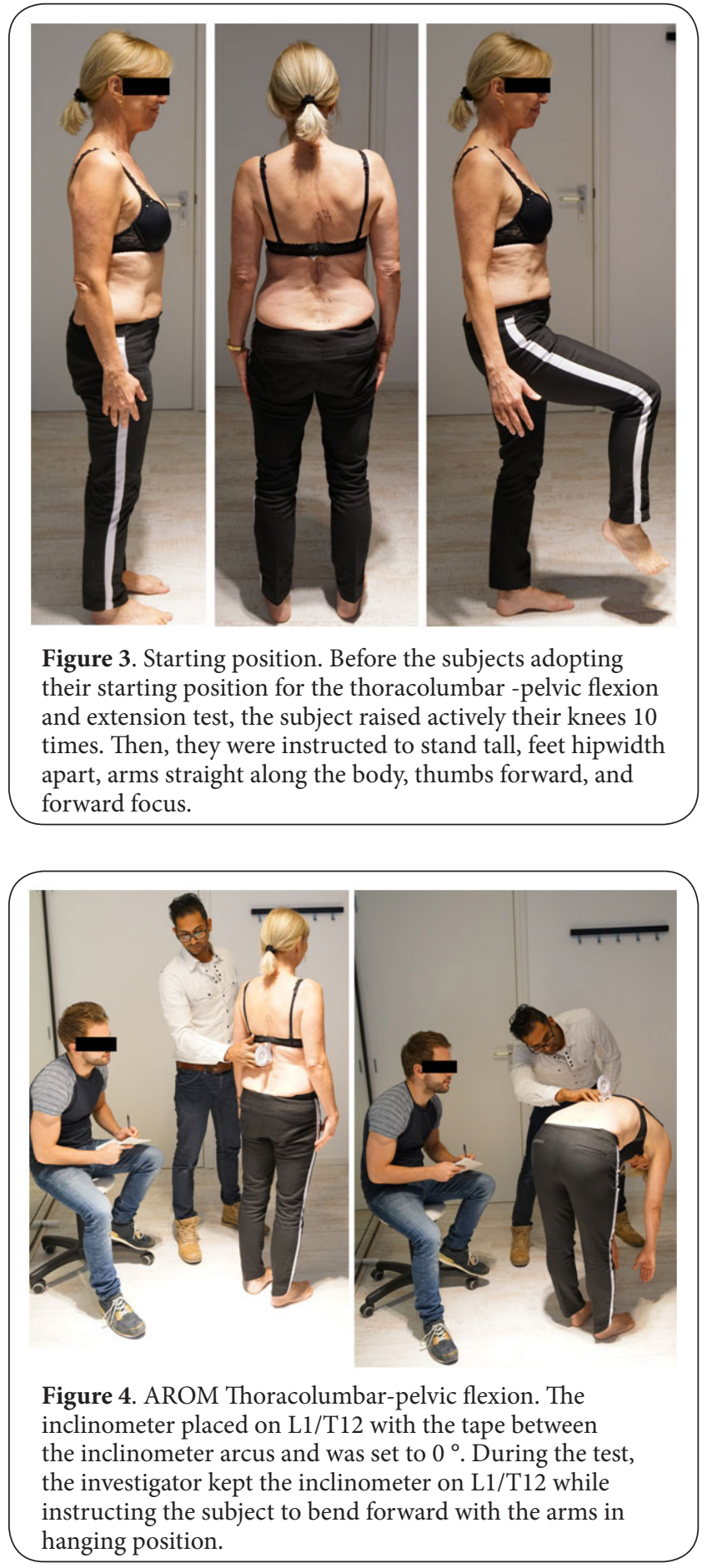

was used in the SPSS program to calculate the sample mean, standard deviation and confidence interval. In order to compare the two groups or distinguish them significantly, the Repeated Measure Analysis of variance mixed design (RMANOVA-MD) was used. Within factor were analysed between: W0-W3 and W7. Between factor were analysed between: experimental group versus Sham group. Finally, interaction between groups $x$ time was analysed.

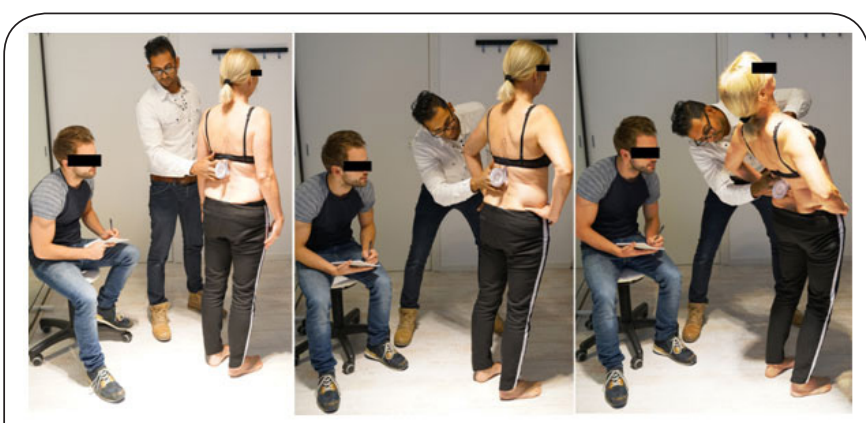

Figure 5. AROM Thoracolumbar-pelvic extension. The inclinometer placed on L1/T12 with the tape between the inclinometer arcus and was set to $0^{\circ}$. During the test, the investigator kept the inclinometer on L1/T12 while instructing the subject to put his hands on his pelvis and bend backwards.

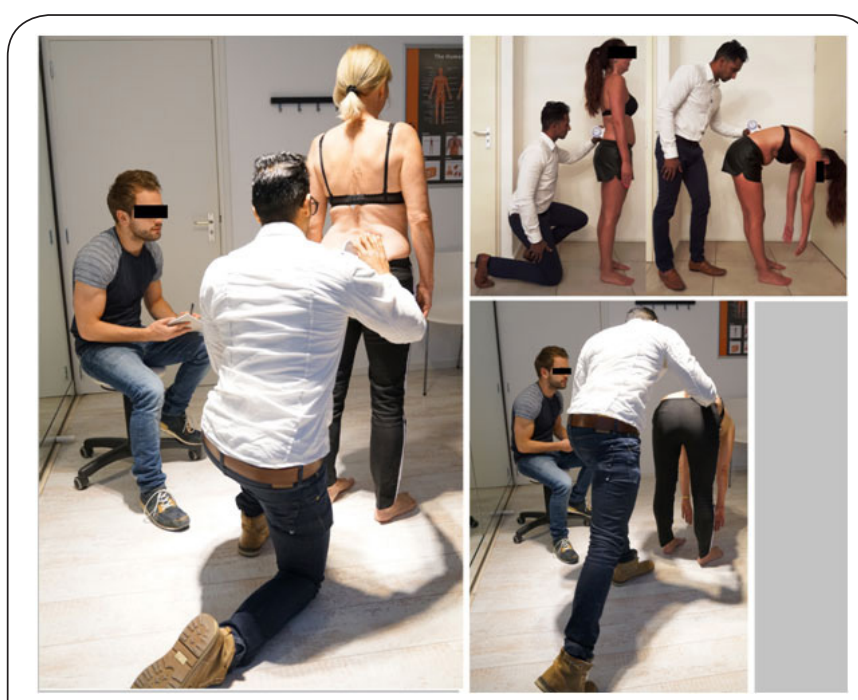

Figure 6. AROM Isolated lumbar flexion test. The inclinometer was moved to labelled S1/S2 and the inclinometer was set to 0 ${ }^{\circ}$. During the test, the investigator held the inclinometer on S1/ S2 while instructing the subject to bend forward. The formula $\sum \mathrm{T} 12 / \mathrm{L} 1-\mathrm{S} 1 / \mathrm{S} 2$ was used.

\section{Sample size}

The sample analysis was performed for the RMANOVA-MD with the Gpower ${ }^{\circ}$ program. The RMANOVA-MD power analysis was performed using the following values: Power.81, Alpha 0.50 , Sample size effect $\mathrm{f} 2=.25$, resulting in a minimum of 28 participants, Fcritical $=3.175$ and an actual power of .82 . Cohen [18] advised a medium-sized effect size $(\mathfrak{f 2}=.25)$ in a RMANOVA-MD. $10 \%$ was added to these 28 participants ( $n=$ 30), towards the possible dropouts. The NSP-CLBP participants are divided into two groups.

\section{Results}

In total, 53 participants in the first round had been registered for participation in this study, of which 11 were directly excluded by telephone screening, because they scored positively 
Amstel et al, Physical Therapy and Rehabilitation 2018,

on the call form. 6 Participants had independently decided to retreat from participating after informative conversation. 1 Participant had signed off for participation, because she had become pregnant. 3 Participants were excluded during the screening for the study, one of them had a radicular pathology L5/S1, which was later confirmed by MRI. Another participant appeared to have had recent trauma with a vertebral fracture T12/L1 and was diagnosed with partial sacralisation. The last one was excluded due to general malaise complaints after a stomach correction and placement of osteosynthetic material L4/L5/S1. Finally, 2 participants had been unsubscribed for reasons unknown. A total of 30 subjects participated in this research. The randomization was performed by a 'blinded' observer, with respect to allocation of subjects under the supervision of the investigator. A total of 15 subjects were randomized to the CGR and 15 subjects for the EGR. In the CGR, 14 subjects followed the therapy, one of the subjects didn't show up at his first appointment for unknown reason. Three subjects stopped during the first three weeks and did not complete the follow-up measurements, because of conflict in activity of daily life (ADL), which led to once a week treatment. In the EGR, 15 subjects have undergone therapy, of which two subjects have not been able to meet the follow-up measurements. One subject stopped because of conflict ADL schedule. The other subject was included in a mental hospital (Figure 7).

\section{Analysis}

Since the intention was to treat, all randomized participants were included in the analysis. For the non-completers, an expectation-maximization intention algorithm was used with the built-in program of SPSS ${ }^{\circledR}$ statistical software for Windows.

The expectation-maximization is a better method than a last

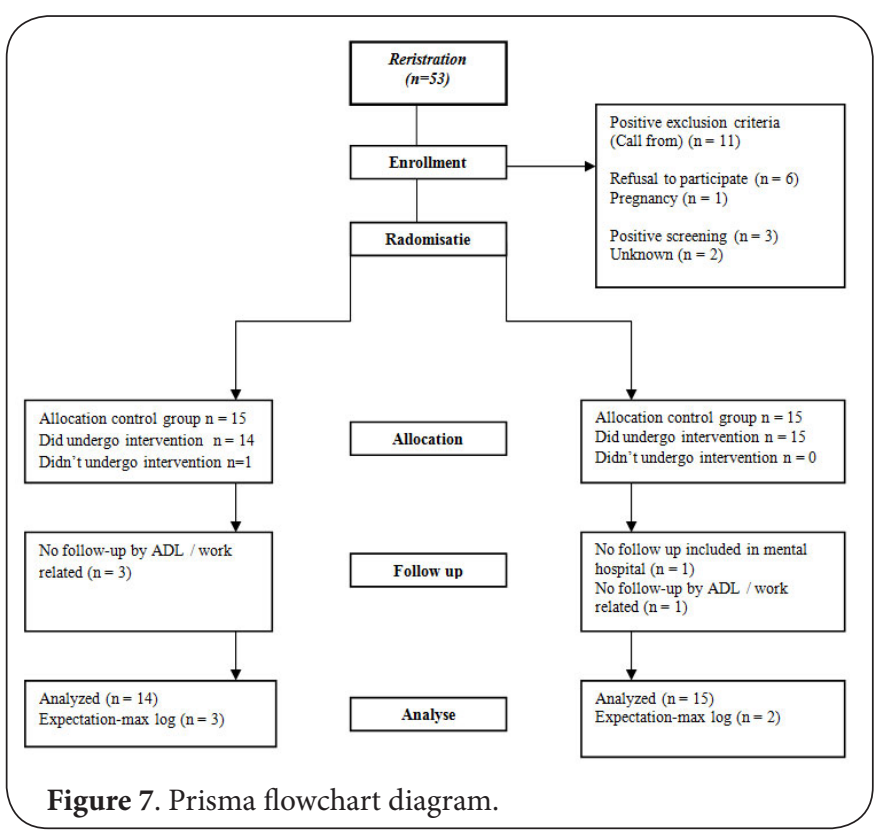

observation carrying forward technique for non-completers $[10,14]$. An analysis was conducted for a total of 29 subjects. In order to analyse the homogeneity of baseline characteristics in W0, the independent sample t-test or Mann Withney $\mathrm{U}$ test was preformed. Homogeneity was accepted at a Levene's F test $p>a=0.01$. The groups were homogeneous for all measurements during the baseline measurement (W0).

The VRS_Classification was calculated by (Table 1).

$$
\frac{W 0 F L_{V R S}+W 0 E T_{V R S}}{2}
$$

\section{Primary and secondary outcome measures}

The changes in our variables were analysed within time: W0-W3, W0-W7 and W3-W7 and for between groups: EGR versus CGR. The results are shown for all variables in a table. The analysis for all variables were significant when $\mathrm{p}<\mathrm{a}=0.05$.

\section{The quality of life EQ 5D 3L and EQ VAS}

After analysing the data, there appears to be a significant interaction effect between time and groups ( $F=4.425, p=0.022)$ (Graph 1). This means that the effect on the dependent, variable QoL measured by EQ-5D-3L-index, depends on the therapy used in the groups and follow up measurement in time, but that both independent variables (groups $x$ time) depend on each other. Interpreting the main effects is not possible. The data was therefore divided into groups, to analyse where the difference was. After splitting files into groups, there appears to be no significant changes within time in CGR for the QoL measured by EQ-5D-3L-index score $(0.565 \pm$ SD 0.298 , $\mathrm{F}=2.167, \mathrm{p}=0.157)$. However, when comparing follow-ups in EGR, a significant difference was found within time for:W0-W3, W0-W7 \& W3-W7 ( $F=13.786, p=0.001)$. This means that the QoL, measured by the EQ-5D-3L-index in this group, shows

Table 1. Baseline Characteristics.

\begin{tabular}{|c|c|c|c|}
\hline Variabeles & $\begin{array}{l}\text { Experimental } \\
\text { group }(n=15)\end{array}$ & $\begin{array}{l}\text { Control group } \\
(n=14)\end{array}$ & $p_{-}$value \\
\hline Age & $45.2 \pm$ SD 11.28 & $44.9 \pm$ SD 10.93 & $\mathrm{p}=0.477$ \\
\hline EQ 5D 3L index & $0.466 \pm$ SD 0.29 & $0.565 \pm$ SD 0.29 & $p=0.660$ \\
\hline EQ 5D 3L VAS & $59.72 \pm$ SD 15.43 & $56.00 \pm$ SD 17.66 & $\mathrm{p}=0.702$ \\
\hline FL_AROM $^{\circ}$ & $87.53 \pm$ SD 20.43 & $98.07 \pm$ SD 18.35 & $\mathrm{p}=0.658$ \\
\hline ET_AROM ${ }^{\circ}$ & $19.36 \pm$ SD 9.30 & $19.57 \pm \mathrm{SD} 7.34$ & $\mathrm{p}=0.187$ \\
\hline FL_Pain_VRS & $5.03 \pm \mathrm{SD} 2.31$ & $3.5 \pm$ SD 2.80 & $\mathrm{p}=0,513$ \\
\hline ET_Pain_VRS & $4.60 \pm \mathrm{SD} 2.60$ & $4.10 \pm \mathrm{SD} 3.00$ & $\mathrm{p}=0.322$ \\
\hline Gender & Man $n=19$ & Female $\mathrm{n}=10$ & $\mathrm{p}=0.368$ \\
\hline${ }^{\star}$ VRS classification & $2.60 \pm \mathrm{SD} 0.82$ & $2.46 \pm$ SD 77.62 & $\mathrm{p}=0.780$ \\
\hline
\end{tabular}

Data is displayed as mean \pm SD and p-value.

a. p-value of independent sample t-test

b. p-value of Mann Whitney U test

c. $\mathrm{FL}=$ flexion, $\mathrm{ET}=$ extension, $\mathrm{AROM}=$ active range of motion in degrees $^{\circ}$

d. VRS $=$ verbal rating score, Vas $=$ visual analogue scale 


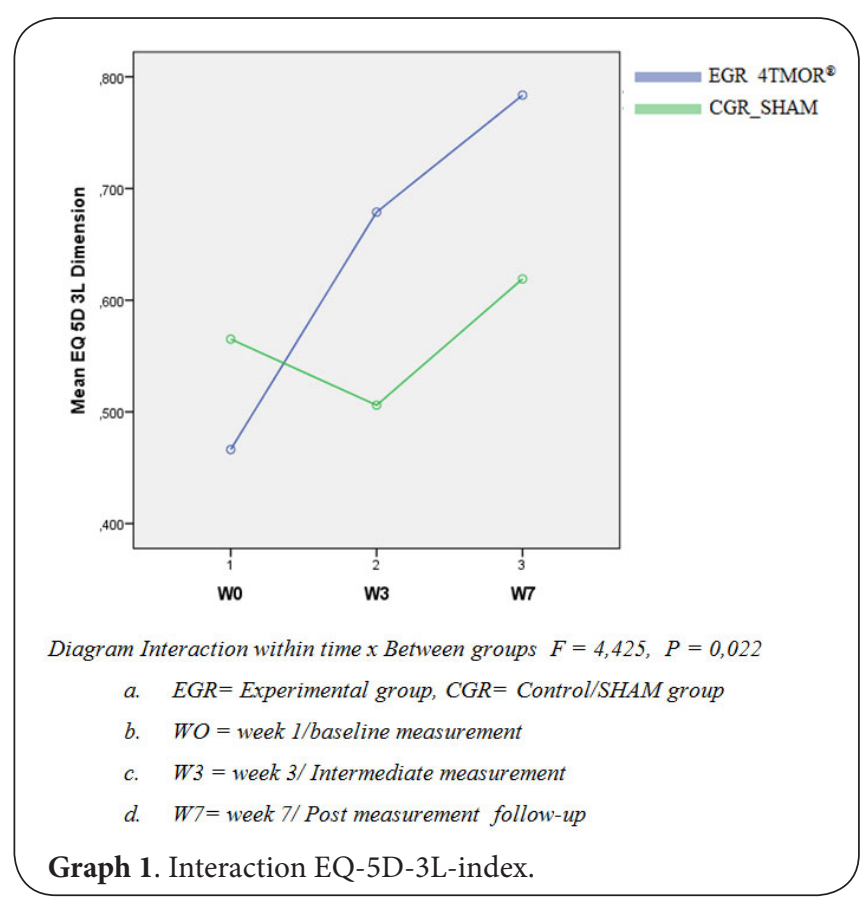

a positive evolution in time. To correct for increased chance of finding an incorrect, significant effect (Type 1 error), we used the Bonferroni post hoc test. This analysis shows that there was a significant difference between the follow-up measurements: W0-W3, W0-W7 \& W3-W7 (Table 2). The QoL measured by EQ-VAS shows a significant improvement within both groups for follow-up measurements ( $F=19.162, p<0.001$ ), therefore, it appears that a positive evolution has been found in both groups. There is no significant difference between the groups on EQ-VAS score $(F=3.426, p=0.075>a=0.05)$. It was apparent from this analysis that EQ-VAS score is not dependent on the therapy used in both groups. EQ-VAS score was the same, and there was a positive evolution in QoL measured with EQ-VAS scores for both groups (Table 3). The Minimal Important Change (MIC) for a Visual Analog Score (VAS) is 15 points [61]. When we looked at our data, it appears that this had only been achieved by the EGR between W0-W7 (Table 4).

\section{AROM flexion and extension (Inclinometer)}

A significant interaction effect was found between the time and the groups in the TLPF AROM ( $F=2.401, p=0.027)$ (Graph 2).

Table 2. Quality of life EQ-5D-3L-index results.

\begin{tabular}{|c|c|c|c|c|c|c|c|c|c|}
\hline \multicolumn{4}{|c|}{ Experimental group } & \multicolumn{6}{|c|}{ Control group } \\
\hline \multirow{2}{*}{$\begin{array}{l}\text { Week } \\
\text { Wo }\end{array}$} & \multirow{2}{*}{$\begin{array}{l}\text { Mean } \\
0.466 \pm S D 0.286\end{array}$} & \multicolumn{2}{|c|}{ 95\% CI } & \multirow{2}{*}{$\begin{array}{l}\text { Mean different } \\
--\end{array}$} & \multirow{2}{*}{$\begin{array}{l}\text { Within } \\
\text { p_value } \\
p=0.005\end{array}$} & \multirow{2}{*}{$\begin{array}{l}\text { Mean } \\
0.565 \pm \text { SD0.298 }\end{array}$} & \multicolumn{2}{|c|}{$95 \% C I$} & \multirow{2}{*}{$\begin{array}{l}\text { Within } \\
p_{-} \text {value } \\
p=N S\end{array}$} \\
\hline & & .308 & .625 & & & & .393 & .738 & \\
\hline W3 & $0.678 \pm$ SD 0.264 & .532 & .825 & -- & $p=0.005$ & $0.506 \pm$ SD 0.270 & .350 & .662 & $p=N S$ \\
\hline$W 7$ & $0.783 \pm \mathrm{SD} 0.191$ & .677 & .890 & -- & $p=0.005$ & $0.619 \pm$ SD0.209 & .498 & .740 & $p=N S$ \\
\hline$W 0-W 3$ & -- & -.388 & -.037 & -.213 & $p=0.016$ & -- & -- & -- & -- \\
\hline$W 0-W 7$ & -- & -.486 & -.148 & -.317 & $p>0.001$ & -- & -- & -- & -- \\
\hline$W 3-W 7$ & -- & -.105 & -.200 & -.009 & $p=0.030$ & -- & -- & -- & -- \\
\hline
\end{tabular}

Data is displayed as mean \pm SD and $p$ - value.

a. p- value of RMANOVA mix design \& Bonferroni post hoc

b. $\mathrm{W} 0=$ week $0 /$ baseline measurement, $\mathrm{W} 3=$ week $3 /$ intermediate measurement, $\mathrm{W} 7=$ week $7 /$ post measurement

c. $\mathrm{NS}=$ not significant

Table 3. Quality of life EQ-VAS results.

\begin{tabular}{|c|c|c|c|c|c|c|}
\hline \multirow{3}{*}{$\frac{\text { Week }}{\text { Wo }}$} & \multicolumn{3}{|c|}{ Experimental group } & \multicolumn{3}{|l|}{ Control group } \\
\hline & \multirow{2}{*}{$\begin{array}{l}\text { Mean } \\
59.72 \pm \text { SD } 15.43\end{array}$} & \multicolumn{2}{|c|}{$95 \%$ CI } & \multirow{2}{*}{$\begin{array}{l}\text { Mean } \\
56.00 \pm \text { SD } 17.66\end{array}$} & $95 \%$ CI & \multirow{2}{*}{$\begin{array}{l}\text { Between p_value } \\
p=N S\end{array}$} \\
\hline & & 51.74 & 68.26 & & $.393 \quad .738$ & \\
\hline W3 & $71.54 \pm$ SD 15.42 & 63.00 & 80.09 & $59.20 \pm \mathrm{SD} 14.84$ & $.350 \quad .662$ & $p=N S$ \\
\hline W7 & $78.63 \pm$ SD 17.14 & 69.03 & 88.02 & $66.65 \pm$ SD 13.54 & $.498 \quad .740$ & $p=N S$ \\
\hline Within p_value & $p<0$. & & & $p<0.0$ & & \\
\hline
\end{tabular}

Data is displayed as mean \pm SD and $p$ - value.

a. $\mathrm{p}$ - value of RMANOVA mix design

b. W0=week 0/baseline measurement, $\mathrm{W} 3=$ week $3 /$ intermediate measurement, $\mathrm{W} 7=$ week $7 /$ post

measurement

c. $\mathrm{CI}=$ confidence interval

d. NS= not significant 
Table 4. MIC EQ-VAS.

\begin{tabular}{lcccccccc}
\hline \multicolumn{3}{c}{ Experimental group } & \multicolumn{5}{c}{ Control group } \\
Week & 95\% CI & MD & MIC & 95\% CI & MD & MIC \\
W0-W3 & -19.11 & -4.54 & -11.82 & $11.82<15$ & -18.55 & 12.15 & -3.20 & $3.20<15$ \\
W0-W7 & -28.44 & -9.17 & -18.81 & $18.81>15$ & -23.35 & 2.04 & -10.65 & $10.65<15$ \\
$W 3-W 7$ & -12.66 & -1.30 & -6.98 & $6.98<15$ & -13.98 & -.91 & -7.45 & $7.45<15$ \\
\hline
\end{tabular}

Data is displayed as confidence interval mean different vs MIC

a. $\mathrm{MD}=$ mean different

b. $\mathrm{MIC}=$ minimal important change, minimal mean full change for patient

c. $\mathrm{CI}=$ Confidence interval

d. Vas $=$ visual analogue scale

e. $\mathrm{W} 0=$ week $0 /$ baseline measurement, $\mathrm{W} 3=$ week $3 /$ intermediate

measurement, $\mathrm{W} 7=$ week $7 /$ post measurement

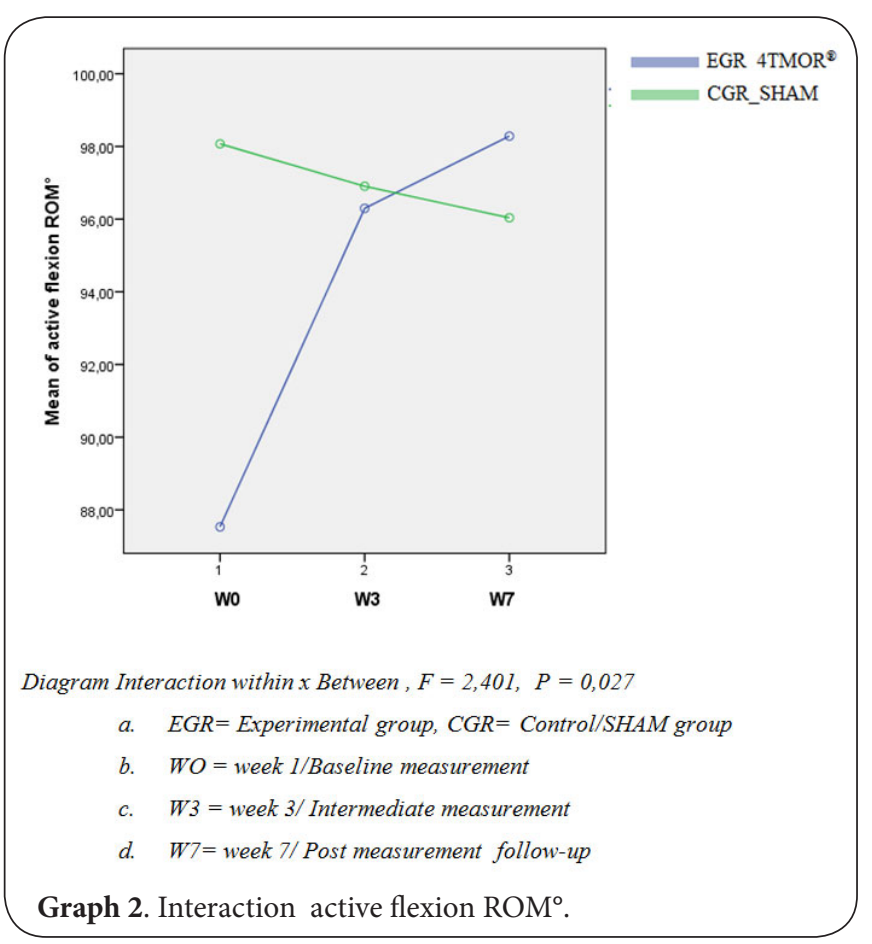

This shows that the effect on the dependent variable AROM measured by the inclinometer, was dependent on the therapy used in the groups and the independent variables time, but that both independent variables depend on each other. Interpreting the main effects was not realistic. In order to properly interpret the data, a split file into groups had been used. After analysis the data, no significant differences were found in the CGR for TLPF AROM measured by the inclinometer $(F=0.182$, $\mathrm{p}=0.836$ ). However, the TLPF AROM increased significantly in the $E G R(F=8.304, p=0.005)$. A Bonferroni post hoc analysis had been performed to see if there was a difference between the follow-up measurements and to exclude a Type 1 error. This analysis shows that there was a significant difference between W0-W3 and W0-W7, no significant difference was found between W3-W7 (Table 5). This observation is confirmed when we looked at the MDC for the TLPF. Between W0-W3 and W0-W7, MDC was exceeded, the opposite we see for W3-W7 where MDC was not reached. This conclusion corresponds to the post hoc results. Also a significant interaction effect was found between time measurements and the groups for the TLPE AROM measured by the inclinometer $(F=3.382, p=0.049)$ (Graph 3). This shows that the effect on the dependent vari-

Table 5. Active range of motion ${ }^{\circ}$ thoracolumbar-pelvic flexion inclinometer results.

\begin{tabular}{|c|c|c|c|c|c|c|c|c|c|}
\hline \multicolumn{6}{|c|}{ Experimental group } & \multicolumn{4}{|l|}{ Control group } \\
\hline \multirow{2}{*}{$\begin{array}{l}\text { Week } \\
\text { Wo }\end{array}$} & \multirow{2}{*}{$\begin{array}{l}\text { Mean } \\
87.53 \pm \text { SD20.45 }\end{array}$} & \multicolumn{2}{|c|}{$95 \% C I$} & \multirow{2}{*}{$\begin{array}{l}\text { Mean } \\
\text { different }\end{array}$} & \multirow{2}{*}{$\begin{array}{l}\text { Within } \\
\text { p_value }\end{array}$} & \multirow{2}{*}{$\begin{array}{l}\text { Mean } \\
98.07 \pm \text { SD } 18.34\end{array}$} & \multicolumn{2}{|c|}{$95 \% C I$} & \multirow{2}{*}{$\begin{array}{l}\begin{array}{l}\text { Within } \\
\text { p_value }\end{array} \\
p=N S\end{array}$} \\
\hline & & 76.21 & 98.84 & & & & 87.47 & 108.6 & \\
\hline$W 3$ & $96.29 \pm \mathrm{SD} 16.34$ & 87.24 & 105.3 & -- & $p=0.005$ & $96.60 \pm$ SD 19.72 & 85.51 & 108.3 & $p=N S$ \\
\hline$W 7$ & $98.28 \pm \mathrm{SD} 17.01$ & 88.86 & 107.7 & -- & $p=0.005$ & $96.03 \pm \mathrm{SD} 18.73$ & 85.22 & 106.9 & $p=N S$ \\
\hline W0-W3 & -- & -14.64 & -2.88 & 8,76 & $p=0.002$ & -- & -- & -- & -- \\
\hline Wo-W7 & -- & -21.66 & -160 & -10.75 & $p=0.015$ & -- & -- & -- & -- \\
\hline W3-W7 & -- & -8.85 & 4.87 & -1.99 & $P=N S$ & -- & -- & -- & -- \\
\hline
\end{tabular}

Data is displayed as mean \pm SD and p- value.

a. p- value of RMANOVA mix design \& Bonferroni post hoc

b. $\mathrm{W} 0=$ week $0 /$ baseline measurement, $\mathrm{W} 3=$ week $3 /$ intermediate measurement, $\mathrm{W} 7=$ week $7 /$ post measurement

c. $\mathrm{CI}=$ Confidence interval

d. NS=not significant 


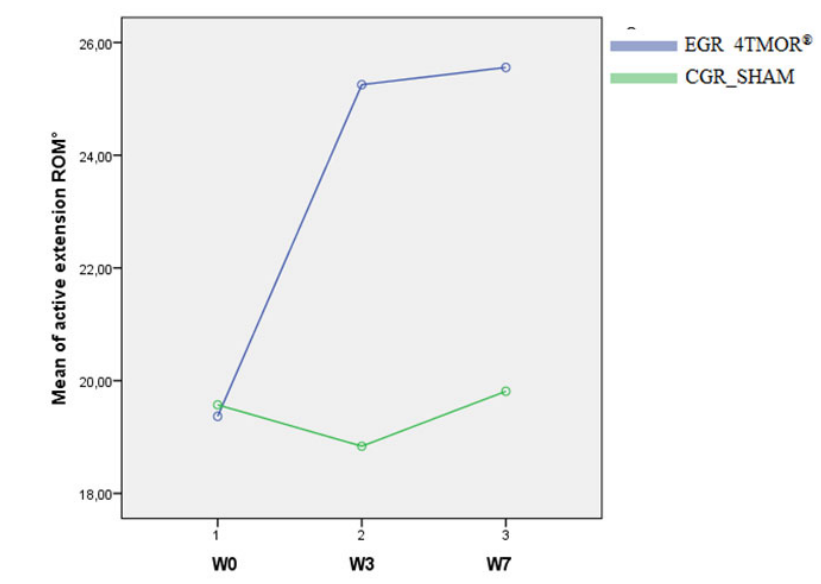

Diagram Interaction within $x$ Between, $F=3,382, \quad P=0,049$

$$
\begin{aligned}
& \text { a. } \quad E G R=\text { Experimental group, } C G R=\text { Control/SHAM group } \\
& \text { b. } W O=\text { week } 1 / \text { Baseline measurement } \\
& \text { c. } \quad W 3=\text { week } 3 / \text { Intermediate measurement } \\
& \text { d. } \quad W 7=\text { week } 7 / \text { Post measurement follow-up }
\end{aligned}
$$

Graph 3. Interaction active extension rom ${ }^{\circ}$.

able AROM measured by the inclinometer is dependent on the therapy used in the groups and the independent variables time, but that both independent variables depend on each other. The main effects cannot be interpreted. No significant changes appeared to be in the CGR in the ROM for the TLPE AROM measured by the inclinometer, after performing a RMANOVA split files into groups ( $F=0.418, p=0.668>a=0.05$ ). Significant evolution was found in the EGR ( $F=5.970, p=0.014)$, a Bonferroni post hoc analysis had been performed to see if there was a difference between the follow-up measurements and to exclude a Type 1 error. This analysis shows that there had been a significant improvement between W0-W3 and W0-W7, no significant difference was found between W3-W7 (Table 6). When we looked at the descriptive data the MDC of $6^{\circ}$ only exceeded between W0-W7 (Table 8). Finally, the ILF AROM was analysed, a significant main effect was found (F4.185, $\mathrm{p}=0.027$ ).

According to the analysis, an improvement could be seen in both groups, there is no significant difference between the groups ( $F=0.0102, p=0.775>a=0.05$ ) (Table 7$)$. The difference was so small, that it was very difficult to correctly interpret this analysis. If there was an improvement, this would be in favour of the CGR, because it had exceeded the $\mathrm{MCD}^{\circ}$ of $9^{\circ}$ between W0-W7.

Pain intensity, flexion and extension (Verbal Rating Scale) The PI during active flexion measured by the VRS scale was dependent on the intervention used ( $F=7.118, p=0.037)$ (Graph 4). This means that the analysed effect on the PI during the active flexion measured by the VRS scale was dependent on the therapy used in the groups and the measurements in time, but that both independent variables depend on each other. Interpreting the main effects could be false and needed to be split into groups. After splitting files into groups, there appeared to be no significant changes in the CGR in the PI

Table 7. Isolated lumbar flexion active range of motion ${ }^{\circ}$ inclinometer results.

\begin{tabular}{llll}
\hline Experimental group & \multicolumn{2}{l}{ Control group } \\
\hline Week & Mean & Mean & $\begin{array}{l}\text { Between } \\
\text { p_value }\end{array}$ \\
\hline W0 & $36.03 \pm \mathrm{SD} 13.43$ & $42.42 \pm 10.40$ & $p=N S$ \\
W3 & $34.96 \pm \mathrm{SD} 11.95$ & $34.87 \pm 11.91$ & $p=N S$ \\
W7 & $34.29 \pm \mathrm{SD} 10.93$ & $31.35 \pm 7.22$ & $p=N S$ \\
Within p_value & $p=0.027$ & & \\
\hline
\end{tabular}

Data is displayed as mean \pm SD and $p$ - value.

a. p-value of RMANOVA mix design \& Bonferroni post hoc b. $\mathrm{W} 0=$ week $0 /$ baseline measurement, $\mathrm{W} 3=$ week $3 /$ intermediate measurement, $\mathrm{W} 7=$ week $7 /$ post measurement

\begin{tabular}{|c|c|c|c|c|c|c|c|c|c|}
\hline \multicolumn{6}{|c|}{ Experimental group } & \multicolumn{4}{|l|}{ Control group } \\
\hline \multirow{2}{*}{$\begin{array}{l}\text { Week } \\
\text { Wo }\end{array}$} & \multirow{2}{*}{$\begin{array}{l}\text { Mean } \\
19.36 \pm \text { SD9.27 }\end{array}$} & \multicolumn{2}{|c|}{$95 \% C I$} & \multirow{2}{*}{$\begin{array}{l}\text { Mean } \\
\text { different }\end{array}$} & \multirow{2}{*}{$\begin{array}{l}\begin{array}{l}\text { Within } \\
\text { p_value }\end{array} \\
p=0.014\end{array}$} & \multirow{2}{*}{$\begin{array}{l}\text { Mean } \\
19.57 \pm \text { SD7.35 }\end{array}$} & \multicolumn{2}{|c|}{$95 \% C I$} & \multirow{2}{*}{$\begin{array}{l}\begin{array}{l}\text { Within } \\
\text { p_value }\end{array} \\
p=N S\end{array}$} \\
\hline & & 14.22 & 24.50 & & & & 15.33 & 23.81 & \\
\hline W3 & $22.25 \pm$ SD 5.99 & 21.93 & 28.57 & -- & $p=0.014$ & $18.83 \pm$ SD6.14 & 15.29 & 22.38 & $p=N S$ \\
\hline W7 & $25.55 \pm$ SD7.30 & 21.51 & 29.60 & -- & $P=0.014$ & $19.81 \pm$ SD5.61 & 16.57 & 23.05 & $p=N S$ \\
\hline$W 0-W 3$ & -- & -10.34 & 1.42 & -5.88 & $p=0.009$ & -- & -- & -- & -- \\
\hline Wo-W7 & -- & -11.40 & -982 & -6.19 & $p=0.018$ & -- & -- & -- & -- \\
\hline$W 3-W 7$ & -- & -1.89 & 2.50 & -.306 & $p=N S$ & -- & -- & -- & -- \\
\hline
\end{tabular}

c. $\mathrm{CI}=$ confidence interval

d. NS= not significant

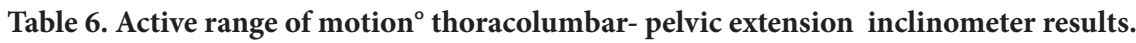

Data is displayed as mean \pm SD and p- value.

a. p- value of RMANOVA mix design \& Bonferroni post hoc

b. $\mathrm{W} 0=$ week $0 /$ baseline measurement, $\mathrm{W} 3=$ week $3 /$ intermediate measurement, $\mathrm{W} 7=$ week $7 /$ post measurement;

c. $\mathrm{CI}=$ confidence interval

d. NS= not significant 


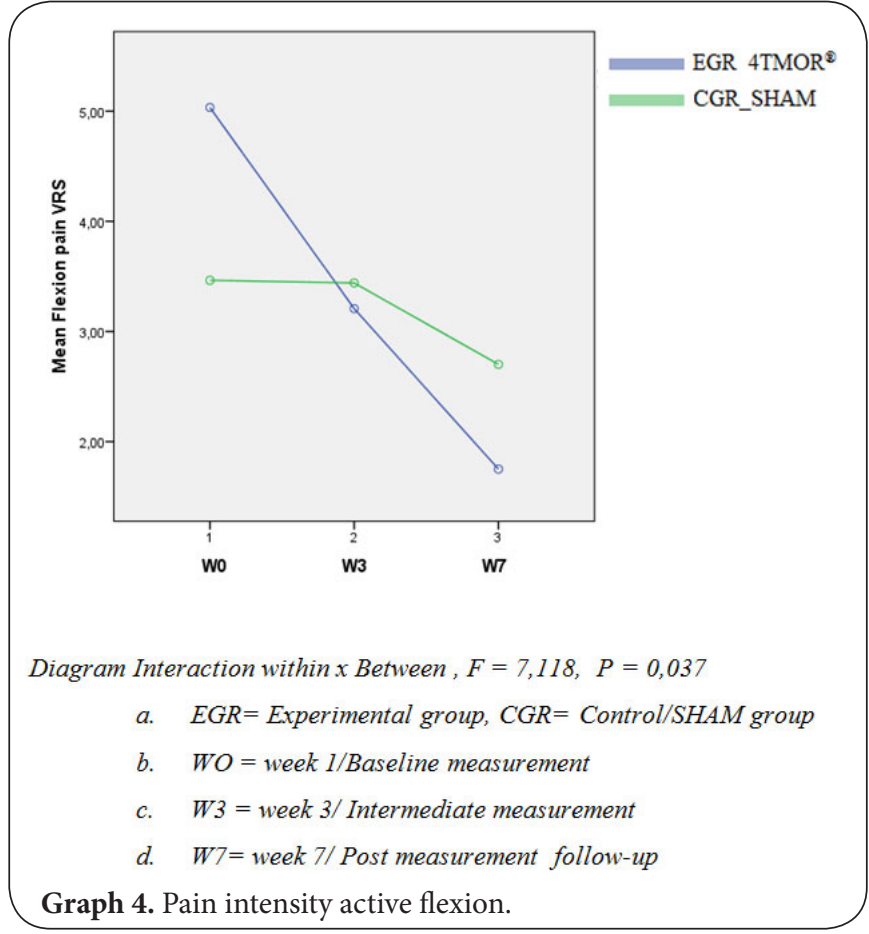

during the active flexion ( $F=0.502, p=0.617)$. Although the $\mathrm{PI}$ decreased significantly in the EGR $(F=16.906, p<0.001)$. In order to correct for the increased chance of finding a type 1 error, we used the Bonferroni post hoc test. This analysis shows a significant difference between W0-W3 and W0-W7, but no significant difference between W3-W7 (Tables 9 and 11). The PI during the extension did not significantly decrease in both groups ( $F=2.880, p=0.074$ ) (Table 10). However, it seems that we had a trend in favour of the EGR, which could also be seen in (Graph 5). We are talking about a trend when the $p$ value is just not smaller than $a=0.05$. The descriptive data for the EGR show that the MIC of 2 points has been exceeded between W0-W7 (Table 12). There may be a small beneficial effect in the EGR that was valuable for NSP-CLBP patient on the $\mathrm{PI}$ during active extension.

\section{Discussion}

One of the purposes of this study was to report the results and to investigate the effect of the 4 MTORß method on QoL, $\mathrm{PI}$ and the AROM in patients with NSP-CLBP, after a period of six weeks of physiotherapeutic back rehabilitation care, twice a week, according to the 4 MTOR $囚$. Another purpose was to

Table 8. $\mathrm{MDC}^{\circ} \mathrm{AROM}$ experimental group.

\begin{tabular}{|c|c|c|c|c|c|c|c|c|}
\hline \multicolumn{5}{|c|}{ Total thoracolumbar-pelvic flexion } & \multicolumn{4}{|c|}{ Total thoracolumbar-pelvic extension } \\
\hline Week & 95 & $C I$ & $M D$ & $\mathrm{MDC}^{\circ}$ & & $\% C I$ & $M D$ & $\mathrm{MDC}^{\circ}$ \\
\hline$W 0-W 3$ & -14.64 & -2.88 & 8.76 & $8.76>7^{\circ}$ & -10.34 & 1.42 & -5.88 & $-5.88<6^{\circ}$ \\
\hline Wo-W7 & -21.66 & -160 & -10.75 & $10.75>7^{\circ}$ & -11.40 & -982 & -6.19 & 6.19 \\
\hline$W 3-W 7$ & -8.85 & 4.87 & -1.99 & $1.99<7^{\circ}$ & -1.89 & 2.50 & -.306 & $-.306<6^{\circ}$ \\
\hline
\end{tabular}

Data is displayed as confidence interval mean different vs MIC

a. $\mathrm{CI}=$ confidence interval

b. $\mathrm{MD}=$ mean different

c. $\mathrm{MDC}=$ minimal detectable change, minimum change in a patient's score that ensures

the change isn't the result of measurement error.

Table 9. Active flexion pain intensity VRS.

\begin{tabular}{|c|c|c|c|c|c|c|c|c|c|}
\hline \multicolumn{4}{|c|}{ Experimental group } & \multicolumn{6}{|c|}{ Control group } \\
\hline \multirow{2}{*}{$\begin{array}{l}\text { Week } \\
\text { Wo }\end{array}$} & \multirow{2}{*}{$\begin{array}{l}\text { Mean } \\
5.03 \pm \text { SD2.3 }\end{array}$} & \multicolumn{2}{|c|}{$95 \% C I$} & \multirow{2}{*}{ Mean different } & \multirow{2}{*}{$\frac{\text { p_value }}{\mathrm{p}<0.001}$} & \multirow{2}{*}{$\begin{array}{l}\text { Mean } \\
3.46 \pm \text { SD2.8 }\end{array}$} & \multicolumn{2}{|c|}{$95 \% C I$} & \multirow{2}{*}{$\begin{array}{l}\text { p_value } \\
\mathrm{p}=\mathrm{NS}\end{array}$} \\
\hline & & 3.75 & 6.31 & & & & 1.85 & 5.07 & \\
\hline W3 & $3.20 \pm \mathrm{SD} 2.7$ & 1.73 & 4.69 & -- & $\mathrm{p}<0.001$ & $3.44 \pm \mathrm{SD} 2.8$ & 1.84 & 5.04 & $\mathrm{p}=\mathrm{NS}$ \\
\hline$W 7$ & $1.75 \pm \mathrm{SD} 2.4$ & 0.395 & 3.10 & -- & $\mathrm{p}<0.001$ & $2.70 \pm \mathrm{SD} 3.6$ & .636 & 4.77 & $\mathrm{p}=\mathrm{NS}$ \\
\hline$W 0-W 3$ & -- & 0.77 & 2.87 & 1.8 & $\mathrm{p}=0.001$ & -- & -- & -- & -- \\
\hline$W 0-W 7$ & -- & 1.619 & 4.94 & 3.3 & $\mathrm{p}<0.001$ & -- & -- & -- & -- \\
\hline$W 3-W 7$ & -- & -.105 & 3.01 & 1.4 & $\mathrm{p}=\mathrm{NS}$ & -- & -- & -- & -- \\
\hline
\end{tabular}

Data is displayed as mean \pm SD and p- value.

a. p- value of RMANOVA mix design \& Bonferroni post hoc

b. $\mathrm{W} 0=$ week $0 /$ baseline measurement, $\mathrm{W} 3=$ week $3 /$ intermediate measurement, $\mathrm{W} 7=$ week $7 /$ post measurement

c. $\mathrm{CI}=$ confidence interval

d. $\mathrm{NS}=$ not significant

e. VRS= Verbal Rating Scale, Pain Scale 
Table 10. Extension pain intensity VRS.

\begin{tabular}{llllllll}
\hline \multicolumn{7}{l}{ Experimentele groep } & \multicolumn{4}{l}{ Controle groep } \\
\hline Week & Mean & \multicolumn{2}{l}{ 95\% CI } & Mean & 95\% CI & Between p_value \\
\hline W0 & $4.60 \pm \mathrm{SD} 2.59$ & 3.16 & 6.03 & $4.07 \pm \mathrm{SD} 2.03$ & 2.34 & 5.80 & $p=N S$ \\
W3 & $2.92 \pm \mathrm{SD} 2.06$ & 1.78 & 4.06 & $4.67 \pm \mathrm{SD} 2.48$ & 3.24 & 6.10 & $p=N S$ \\
W7 & $2.08 \pm \mathrm{SD} 2.67$ & .60 & 3.56 & $4.15 \pm \mathrm{SD} 2.93$ & 2.46 & 5.85 & $p=N S$ \\
Whthin $\boldsymbol{p}$ value & $p=N S$ & & $p=N S$ & & & \\
\hline
\end{tabular}

Data is displayed as mean \pm SD and $p$ - value.

a. $\mathrm{p}$ - value of RMANOVA mix design

b. $\mathrm{W} 0=$ week $0 /$ baseline measurement, $\mathrm{W} 3=$ week $3 /$ intermediate measurement,

$\mathrm{W} 7=$ week $7 /$ post measurement

c. $\mathrm{CI}=$ confidence interval

d. NS= not significant

e. VRS $=$ Verbal Rating Scale, Pain Scale

Table 11. Active flexion pain intensity VRS, minimal important change.

\begin{tabular}{|c|c|c|c|c|c|c|c|c|}
\hline \multicolumn{7}{|c|}{ Experimentele groep } & \multicolumn{2}{|c|}{ Controle groep } \\
\hline Week & & $\% C I$ & $M D$ & MIC & & $\% C I$ & $M D$ & MIC \\
\hline W0-W3 & -.214 & 3.57 & 1.7 & $1.7<2$ & 2.83 & 1.63 & -.600 & $-.600<2$ \\
\hline$W 0-W 7$ & -.418 & 4.61 & 2.5 & $2.5>2$ & 2.30 & 2.12 & -.886 & $-.886<2$ \\
\hline$W 3-W 7$ & -.362 & 2.04 & .84 & $.84<2$ & -1.08 & 2.11 & -.514 & $-.514<2$ \\
\hline
\end{tabular}

Data is displayed as confidence interval mean different vs MIC

a. $\mathrm{MD}=$ mean different

b. $\mathrm{MIC}=$ minimal important change, minimal mean full change for patient.

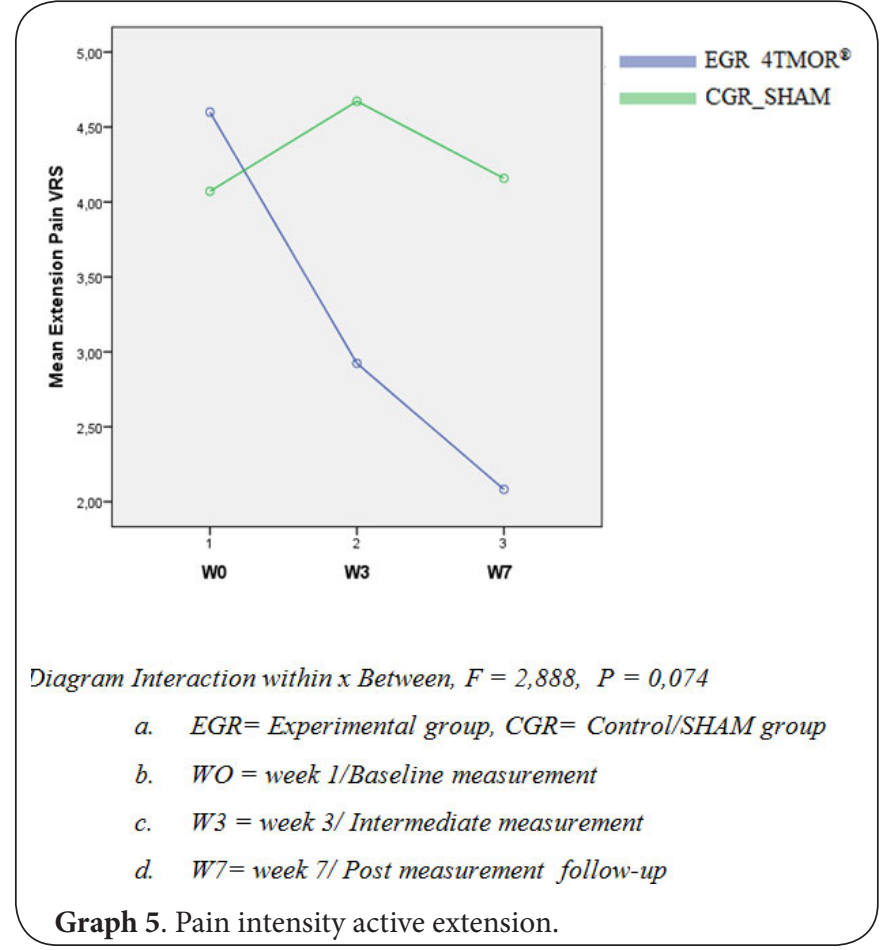

determine whether further investigation into this $4 M T O R \circledast$ method could have an added value. A total of 30 subjects had been randomized in this research, however, a total of 6 participants dropped out for several reasons. Due to these dropouts, we dived under our power of $82 \%$ and we should
Tab1e 12. Active extension pain intensity VRS, minimal important change.

\begin{tabular}{lllll}
\hline & \multicolumn{5}{c}{ Experimentele groep } \\
Week & \multicolumn{2}{c}{ 95\% CI } & MD & MIC \\
W0-W3 & 0.77 & 2.87 & 1.8 & $1.8<2$ \\
$W 0-W 7$ & 1.619 & 4.94 & 3.3 & $3.3>2$ \\
$W 3-W 7$ & -.105 & 3.01 & 1.4 & $1.4<2$ \\
\hline
\end{tabular}

Data is displayed as confidence interval mean different vs MIC

a. $\mathrm{MD}=$ mean different

b. $\mathrm{MIC}=$ minimal important change

c. $\mathrm{W} 0=$ week $0 /$ baseline measurement, $\mathrm{W} 3=$ week

$3 /$ intermediate measurement, $\mathrm{W} 7=$ week $7 /$ post

measurement

d. $\mathrm{CI}=$ confidence interval

be careful about interpreting our data. The effect on QoL, PI and AROM have not previously been investigated in NSPCLBP by this 4 MTOR $®$ method. The 4 MTOR $®$ consists of 4 dimensions, Testing, Triggering, Taping and Training, and was compared to an control group who received exercise therapy with sham manual intervention and sham ET. The costs of care for neck and back is 1.3 billion euros a year. The proportion of care costs for neck and back problems is greater for women (61\%) than for men (39\%) [36]. In this study, the proportion of women $(n=10)$ was lower than men $(n=19)$, which could distort the reality.

\section{Quality of life}

QoL is an important outcome in chronic complaints, and is 
Amstel et al, Physical Therapy and Rehabilitation 2018,

http://www.hoajonline.com/journals/pdf/2055-2386-5-2.pdf

doi: 10.7243/2055-2386-5-2

therefore often used in the analysis of chronic conditions, including cardiac, lung-and cancer patients. From current science it is advised to measure the QoL in CLBP [15]. However, there are few effects studies measured the QoL in patients with CLBP. The Cochrane review of Rubinstein et al [68] shows that physiotherapeutic manual interventions don't affect the QoL and PI. In this study, the QoL seems to be positively influenced in the EGR. The QoL only increases significantly in the CGR measured with EQ-VAS. In previous studies, it was shown that various exercise/training therapy can contribute to improving QoL measured between week 0 - week 8 , this was not analysed by EQ-5D [19,39]. Hurley et al [27] analysed the QoL with the EQ-5D at $n=246$ subjects. Firstly they compared three interventions: running program, training class and physiotherapy. All interventions showed a significant difference on the EQ-5D-3L-index $(p<0.05)$. Whynes et al [84] using the EQ-5D-3L-index and the EQ-VAS to evaluate the QoL in CLPB patients, they concluded that EQ-5D-3L-index measures other conceptual changes than EQ-VAS. This could maybe also been the case in this research. Secondly, they measured the responsiveness of the EQ-5D-3L based on 3 measure moments: week 0 , week 2 and week 12 . We also used three measure moments: week 0 , week 3 , week 7 . The major question is, whether this research was representative for this NSP-CLBP population, was the follow-up long enough? In addition, the EQ-5D was evaluated during the therapy period, but what if NSP-CLBP patients do not get treatments. What will happen between week 7 and week 12 with QoL? These are important factors which remain unanswered in this research.

\section{Active Range of motion $^{\circ}$ flexion and extension (Incli- nometer)}

In this study, only the AROM improved significantly in the EGR and not in the CGR. In this study, a bubble inclinometer was used. The bubble inclinometer uses a fixed reference point that has been determined in advance. The data is represented by gravity. Before the data can and may be determined, the inclinometer is always set to zero. When the subject is moving forward or backward at one of the AROM tests, the skin shifts; this may be resulting in errors during the analysis. The AROM extension is more difficult to measure than the AROM flexion and will show less rapid significant improvements [70]. This could also be seen in our research. The technique for holding the bubble inclinometer must be practiced, hence the researcher must be trained in using the bubble inclinometer. Measuring the spinal movement may be problematic in a clinical setting, which may be due to the limitations of simple measuring instruments as a inclinometer [62]. The blinded' observer who was masked for allocation of the subjects did not know whether the subject had physiotherapeutic care in CGR or EGR. The observer's task was to read the inclinometer during these tests with the placement of the inclinometer performed by a trained researcher. We did not analyse the inter-assessment reliability between the investigator and the 'blinded' observer who was masked for allocation of the subjects.

\section{Verbal rating scores VRS}

The VRS was used to score the PI by the participant during active flexion and extension. The VRS and Verbal Numeric Rating Scale (VNRS) are both practically easier to use than a Visual Analogue Scale (VAS) [29]. It also appears that VAS and NRS can detect better a difference in PI than the VRS [12]. In this study, we see no significant improvement in PI during extension, but the MIC of 2 points has been exceeded between W0-W7 in favour of EGR. This may be due to the less ability to detect a change of the VRS.

\section{Conclusion}

The QoL was positively influenced, measured with EQ-5D3L-index and the EQ-VAS within W0-W3, W0-W7 and W3-W7 in the EGR $(p<0.005)$. The QoL was positively influenced during a 6-week intervention according to the 4 MTOR ${ }$. The biggest effect was measured in the first 3 weeks, when they had received a total of 6 treatments ( $W 0=0.466 \pm S D 0.286$ to $W 3=0.678 \pm S D 0.264, p<0.005)$. The AROM increased significantly and clinically for the TLPF AROM in WO $=87.53^{\circ} \pm S D$ $20.45^{\circ}$ to $\mathrm{W} 3=96.29^{\circ} \pm$ SD $16.34^{\circ}$ to $\mathrm{W} 7=98.28^{\circ} \pm$ SD $17.01^{\circ}$, $\mathrm{p}<0.005$. We can conclude that the lumbar spinal mobility significantly increased in flexion direction of the subjects in this study, who have had physical therapy according to the $4 M T O R \otimes$. The TLPE AROM increased significantly over time in the EGR, however, the MCD was reached between W0-W7 $\left(\mathrm{ROM}=6.19^{\circ}>\mathrm{MDC} 6^{\circ}\right)$. This shows that the TLPE mobility is clinically relevant for practice only after 12 treatments. The PI 0-10 points significantly reduced during active flexion in time, clinical relevance was observed between W0-W7 $(\mathrm{W} 0=5.03 \pm S D 2,3$ to $W 7=1.75 \pm S D 2.45, p=0.001 / V R S 6.1>$ MDC 2). This means that the patient actually experiences less pain during active flexion after 12 treatments with the $4 M T O R \circledast$ in this research. The PI didn't significantly decrease for extension, but a clinical relevance was found between W0-W7. The PI can therefore be positively influenced by the $4 M T O R \circledast$. We could conclude from the data in this research that the $4 M T O R \circledast$ according to Noten [58] offers possibilities for positively influencing the QoL, the movement outcome and the active pain experience in CLBP. To see if a protocolbased multimodal physiotherapy intervention, according to

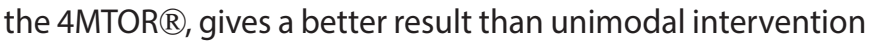
based physiotherapy, further investigation is required. This sample is too small to make an actual statement about the achieved result of the increased QoL, AROM and reduced PI. Further research has to be carried out on this method, with more statistical power.

\section{Competing interests}

The authors declare that they have no competing interests. 
Amstel et al, Physical Therapy and Rehabilitation 2018,

\section{Authors' contributions}

\begin{tabular}{|l|c|c|c|}
\hline Authors' contributions & RVM & PV & SM \\
\hline Research concept and design & $\checkmark$ & $\checkmark$ & -- \\
\hline Collection and/or assembly of data & $\checkmark$ & -- & -- \\
\hline Data analysis and interpretation & $\checkmark$ & -- & -- \\
\hline Writing the article & $\checkmark$ & -- & -- \\
\hline Critical revision of the article & $\checkmark$ & $\checkmark$ & $\checkmark$ \\
\hline Final approval of article & $\checkmark$ & $\checkmark$ & $\checkmark$ \\
\hline Statistical analysis & $\checkmark$ & -- & -- \\
\hline
\end{tabular}

\section{Acknowledgement}

I would like to thank Anne Pijpers for the fine cooperation. She helped very well and assisted in organizing this research. In this respect she was the link between me and the organisation of Sport Medical Expertise and Rehabilitation Centre. In particular, I would like to express my gratitude to my promoter Professor Doctor Vaes. I would like to thank him for the fine cooperation and in particular, for giving me the opportunity to do this research. In addition, I would like to thank my script counsellor assistant professor Master of science S. Malone for the good guidance. You have given me the right handles in order to choose the right direction.

Publication history

Editor: Mohammad H. Hadadzadeh, Wheeling Jesuit University, USA. Received: 15-Dec-2017 Final Revised: 12-Mar-2018

Accepted: 20-Mar-2018 Published: 08-Apr-2018

\section{References}

1. Added MA, Costa LO, Fukuda TY, de Freitas DG, Salomao EC, Monteiro RL and Costa Lda C. Efficacy of adding the Kinesio Taping method to guideline-endorsed conventional physiotherapy in patients with chronic nonspecific low back pain: a randomised controlled trial. $B M C$ Musculoskelet Disord. 2013; 14:301. | Article | PubMed Abstract | PubMed FullText

2. Added MA, Costa LO, de Freitas DG, Fukuda TY, Monteiro RL, Salomao EC, de Medeiros FC and Costa Lda C. Kinesio Taping Does Not Provide Additional Benefits in Patients With Chronic Low Back Pain Who Receive Exercise and Manual Therapy: A Randomized Controlled Trial. J Orthop Sports Phys Ther. 2016; 46:506-13. | Article | PubMed

3. Ajimsha MS, Daniel B and Chithra S. Effectiveness of myofascial release in the management of chronic low back pain in nursing professionals. $J$ Bodyw Mov Ther. 2014; 18:273-81. | Article | PubMed

4. van Amstel R.N, Vaes $P$ and Malone S. Flexibility after physiotherapeutic intervention in chronic low back pain: A systematic review, [thesis]. Rehabilitation en movement science, The University of Brussels. 2014.

5. Areeudomwong P, Wongrat W, Neammesri $\mathrm{N}$ and Thongsakul T. A randomized controlled trial on the long-term effects of proprioceptive neuromuscular facilitation training, on pain-related outcomes and back muscle activity, in patients with chronic low back pain. Musculoskeletal Care. 2017; 15:218-229. | Article | PubMed

6. Arguisuelas M.D.. Lisón, J.F. Sánchez-Zuriaga D, Martínez-Hurtado I and Doménech-Fernández J. Effects of Myofascial Release in Nonspecific Chronic Low Back Pain: A Randomized Clinical Trial, Spine (Phila Pa 1976), 2017; 42:627-634.. | Article

7. Bae SH, Lee JH, Oh KA and Kim KY. The effects of kinesio taping on potential in chronic low back pain patients anticipatory postural control and cerebral cortex. J Phys Ther Sci. 2013; 25:1367-71. | Article | PubMed Abstract | PubMed FullText

8. Bialosky JE, George SZ, Horn ME, Price DD, Staud R and Robinson ME. Spinal manipulative therapy-specific changes in pain sensitivity in individuals with low back pain (NCT01168999). J Pain. 2014; 15:136-48. | Article | PubMed Abstract | PubMed FullText
9. Bicalho E, Setti JA, Macagnan J, Cano JL and Manffra EF. Immediate effects of a high-velocity spine manipulation in paraspinal muscles activity of nonspecific chronic low-back pain subjects. Man Ther. 2010; 15:469-75. | Article | PubMed

10. Blankers M, Koeter MW and Schippers GM. Missing data approaches in eHealth research: simulation study and a tutorial for nonmathematically inclined researchers. J Med Internet Res. 2010; 12:e54. | Article | PubMed Abstract | PubMed FullText

11. Borges J, Baptista AF, Santana N, Souza I, Kruschewsky RA, Galvao-Castro $B$ and Sa KN. Pilates exercises improve low back pain and quality of life in patients with HTLV-1 virus: a randomized crossover clinical trial. J Bodyw Mov Ther. 2014; 18:68-74. | Article | PubMed

12. Breivik H, Borchgrevink P.C, Allen S.M, Rosseland L.A, Romundstad L, Hals E.K, Kvarstein $G$ and Stubhaug A. Assessment of pain. British Journal of Anaesthesia. 2008; 101:17-24. I Article

13. Bronfort $G$, Haas M, Evans RL and Bouter LM. Efficacy of spinal manipulation and mobilization for low back pain and neck pain: a systematic review and best evidence synthesis. Spine J. 2004; 4:335-56. | Article | PubMed

14. Jo $B$, Asparouhov T and Muthen BO. Intention-to-treat analysis in cluster randomized trials with noncompliance. Stat Med. 2008; 27:5565-77. | Article | PubMed Abstract | PubMed FullText

15. Chapman JR, Norvell DC, Hermsmeyer JT, Bransford RJ, DeVine J, McGirt $\mathrm{MJ}$ and Lee MJ. Evaluating common outcomes for measuring treatment success for chronic low back pain. Spine (Phila Pa 1976). 2011; 36:S5468. | Article | PubMed

16. Chen YH, Chai HM, Shau YW, Wang CL and Wang SF. Increased sliding of transverse abdominis during contraction after myofascial release in patients with chronic low back pain. Man Ther. 2016; 23:69-75. | Article I PubMed

17. Clare HA, Adams R and Maher CG. Reliability of McKenzie classification of patients with cervical or lumbar pain. J Manipulative Physiol Ther. 2005; 28:122-7. | Article | PubMed

18. Cohen J. Statistical power analysis for the behavioral sciences (2nd ed.). Hillsdale, NJ: Erlbaum. 1988.

19. Coulombe BJ, Games KE, Neil ER and Eberman LE. Core Stability Exercise Versus General Exercise for Chronic Low Back Pain. J Athl Train. 2017; 52:71-72. | Article | PubMed Abstract | PubMed FullText

20. Cuesta-Vargas AI, Garcia-Romero JC, Arroyo-Morales M, Diego-Acosta AM and Daly DJ. Exercise, manual therapy, and education with or without high-intensity deep-water running for nonspecific chronic low back pain: a pragmatic randomized controlled trial. Am J Phys Med Rehabil. 2011; 90:526-34; quiz 535-8. I Article I PubMed

21. Cuesta-Vargas Al, Gonzalez-Sanchez M and Casuso-Holgado MJ. Effect on health-related quality of life of a multimodal physiotherapy program in patients with chronic musculoskeletal disorders. Health Qual Life Outcomes. 2013; 11:19. | Article | PubMed Abstract | PubMed FullText

22. Cuesta-Vargas Al, White M, Gonzalez-Sanchez M and Kuisma R. The optimal frequency of aquatic physiotherapy for individuals with chronic musculoskeletal pain: a randomised controlled trial. Disabil Rehabil. 2015; 37:311-8. | Article | PubMed

23. Davin $J$ and Callaghan $M$. Towards evidence based emergency medicine: Best BETs from the Manchester Royal Infirmary. BET 2: Core stability versus conventional exercise for treating non-specific low back pain. Emerg Med J. 2016; 33:162-3. | Article | PubMed

24. George JW, Skaggs CD, Thompson PA, Nelson DM, Gavard JA and Gross GA. A randomized controlled trial comparing a multimodal intervention and standard obstetrics care for low back and pelvic pain in pregnancy. Am J Obstet Gynecol. 2013; 208:295 e1-7. | Article | PubMed

25. Hodges PW. Core stability exercise in chronic low back pain. Orthop Clin North Am. 2003; 34:245-54. | Article I PubMed

26. Hodges PW and Richardson CA. Inefficient muscular stabilization of the lumbar spine associated with low back pain. A motor control evaluation of transversus abdominis. Spine (Phila Pa 1976). 1996; 21:2640-50. | Article | PubMed

27. Hurley DA, Tully MA, Lonsdale C, Boreham CA, van Mechelen W, Daly L, 
Amstel et al, Physical Therapy and Rehabilitation 2018,

Tynan A and McDonough SM. Supervised walking in comparison with fitness training for chronic back pain in physiotherapy: results of the SWIFT single-blinded randomized controlled trial (ISRCTN17592092). Pain. 2015; 156:131-47. | Article | PubMed

28. Hides J, Stanton W, Mendis MD and Sexton M. The relationship of transversus abdominis and lumbar multifidus clinical muscle tests in patients with chronic low back pain. Man Ther. 2011; 16:573-7. | Article I PubMed

29. Hjermstad MJ, Fayers PM, Haugen DF, Caraceni A, Hanks GW, Loge JH, Fainsinger R, Aass $\mathrm{N}$ and Kaasa S. Studies comparing Numerical Rating Scales, Verbal Rating Scales, and Visual Analogue Scales for assessment of pain intensity in adults: a systematic literature review. J Pain Symptom Manage. 2011; 41:1073-93. | Article | PubMed

30. Jorritsma $W$ and Mulder $B$. Anatomie in vivo : handleiding bij het Anatomie in vivo-onderwijs aan Academies voor Fysiotherapie. Uitgever onbekend. 1984.

31. Imagama S, Matsuyama $Y$, Hasegawa $Y$, Sakai $Y$, Ito $Z$, Ishiguro $N$ and Hamajima N. Back muscle strength and spinal mobility are predictors of quality of life in middle-aged and elderly males. Eur Spine J. 2011; 20:954-61. | Article | PubMed Abstract | PubMed FullText

32. Kase K, Wallis J and Kase T. Clinical Therapeutic Applications of the Kinesio Taping Method. Tokyo,Japan, Ken Ikai Co Ltd. 13-14; 2003.

33. Kent $\mathrm{P}, \mathrm{Mjosund} \mathrm{HL}$ and Petersen $\mathrm{DH}$. Does targeting manual therapy and/or exercise improve patient outcomes in nonspecific low back pain? A systematic review. BMC Med. 2010; 8:22. | Article | PubMed Abstract | PubMed FullText

34. Krismer $M$ and van Tulder $M$. Strategies for prevention and management of musculoskeletal conditions. Low back pain (non-specific). Best Pract Res Clin Rheumatol. 2007; 21:77-91. | Article | PubMed

35. Koch-Remmele $C$. Funktionskrankheiten des Bewegungssystems nach Brügger,Diagnostik, Therapie, Eigentherapie, Springer. Heidelberg. 2007.

36. Koes, B.W. Nek-en rugklachten Cijfers \& Context Oorzaken en gevolgen. Volksgezondheidenzorg.info. 2017. I Website

37. Koes B.W and van Tulder M.W. Nek- en rugklachten samengevat. In: Volksgezondheid Toekomst Verkenning, Nationaal Kompas Volksgezondheid. Bilthoven. RIVM. Het Rijksinstituut voor Volksgezondheid en Milieu. 2017. | Website

38. Kolber MJ, Pizzini M, Robinson A, Yanez D and Hanney WJ. The reliability and concurrent validity of measurements used to quantify lumbar spine mobility: an analysis of an iphone(R) application and gravity based inclinometry. Int I Sports Phys Ther. 2013; 8:129-37. | PubMed Abstract I PubMed FullText

39. Kofotolis N, Kellis E, Vlachopoulos SP, Gouitas I and Theodorakis Y. Effects of Pilates and trunk strengthening exercises on health-related quality of life in women with chronic low back pain. J Back Musculoskelet Rehabil. 2016; 29:649-659. | Article | PubMed

40. Kumar S, Negi MP, Sharma VP, Shukla R, Dev R and Mishra UK. Efficacy of two multimodal treatments on physical strength of occupationally subgrouped male with low back pain. J Back Musculoskelet Rehabil. 2009; 22:179-88. | Article | PubMed

41. Kumar S, Sharma VP, Shukla R and Dev R. Comparative efficacy of two multimodal treatments on male and female sub-groups with low back pain (part II). J Back Musculoskelet Rehabil. 2010; 23:1-9. | Article | PubMed

42. Laird RA, Gilbert J, Kent $P$ and Keating JL. Comparing lumbo-pelvic kinematics in people with and without back pain: a systematic review and meta-analysis. BMC Musculoskelet Disord. 2014; 15:229. | Article | PubMed Abstract | PubMed FullText

43. Lara-Munoz C, De Leon SP, Feinstein AR, Puente A and Wells CK. Comparison of three rating scales for measuring subjective phenomena in clinical research. I. Use of experimentally controlled auditory stimuli. Arch Med Res. 2004; 35:43-8. | Article I PubMed

44. Lee CW, Hyun J and Kim SG. Influence of pilates mat and apparatus exercises on pain and balance of businesswomen with chronic low back pain. J Phys Ther Sci. 2014; 26:475-7. | Article | PubMed Abstract | PubMed FullText
45. Lee $\mathrm{CW}$, Hwangbo $\mathrm{K}$ and Lee IS. The effects of combination patterns of proprioceptive neuromuscular facilitation and ball exercise on pain and muscle activity of chronic low back pain patients. J Phys Ther Sci. 2014; 26:93-6. | Article | PubMed Abstract | PubMed FullText

46. Lim EC and Tay MG. Kinesio taping in musculoskeletal pain and disability that lasts for more than 4 weeks: is it time to peel off the tape and throw it out with the sweat? A systematic review with meta-analysis focused on pain and also methods of tape application. Br J Sports Med. 2015; 49:1558-66. | Article | PubMed

47. Machado LA, de Souza M, Ferreira PH and Ferreira ML. The McKenzie method for low back pain: a systematic review of the literature with a meta-analysis approach. Spine (Phila Pa 1976). 2006; 31:E254-62. | Article | PubMed

48. Machado LA, Maher CG, Herbert RD, Clare H and McAuley JH. The effectiveness of the McKenzie method in addition to first-line care for acute low back pain: a randomized controlled trial. BMC Med. 2010; 8:10. | Article | PubMed Abstract | PubMed FullText

49. May S and Ross J. The McKenzie classification system in the extremities: a reliability study using Mckenzie assessment forms and experienced clinicians. J Manipulative Physiol Ther. 2009; 32:556-63. | Article | PubMed

50. McKenzie R.A and May S. The Lumbar Spine. Mechanical Diagnosis and Therapy. (Vol. 1 and 2) Spinal Publications, 2nd Edition, New Zealand: Spinal Publications. 2003.

51. MacDermid JC, Arumugam V, Vincent JI and Carroll KL. The reliability and validity of the computerized double inclinometer in measuring lumbar mobility. Open Orthop J. 2014; 8:355-60. | Article | PubMed Abstract | PubMed FullText

52. Meeusen R. Functional trainingstherapy. College lecturers. University Brussel. 2014.

53. Meeus M, Roussel NA, Truijen S and Nijs J. Reduced pressure pain thresholds in response to exercise in chronic fatigue syndrome but not in chronic low back pain: an experimental study. J Rehabil Med. 2010; 42:884-90. | Article | PubMed

54. Miro J, Castarlenas E, de la Vega R, Sole E, Tome-Pires C, Jensen MP, Enge $J M$ and Racine $M$. Validity of three rating scales for measuring pain intensity in youths with physical disabilities. Eur J Pain. 2016; 20:130-7. | Article | PubMed Abstract | PubMed FullText

55. Morris D, Jones D, Ryan H and Ryan CG. The clinical effects of Kinesio(R) Tex taping: A systematic review. Physiother Theory Pract. 2013; 29:25970. | Article | PubMed

56. Mostafavifar M, Wertz J and Borchers J. A systematic review of the effectiveness of kinesio taping for musculoskeletal injury. Phys Sportsmed. 2012; 40:33-40. | Article | PubMed

57. Noten K. De beste oefeningen bij rugklachten. 1e druk ,Uithoorn:Karakter Uitgevers B.V. 2007.

58. Noten K. Orthopedische revalidatie 4xt-methode. College lecturers. Fysio Physics, IJsselstein. 2012.

59. Neubauer E, Zahlten-Hinguranage A, Schiltenwolf $M$ and Buchner M. Multimodale Therapie bei chronischem HWS und LWS-Schmerz. Schmerz. 2006; 20:210-8.

60. Obradovic $M$, Lal $A$ and Liedgens $H$. Validity and responsiveness of EuroQol-5 dimension (EQ-5D) versus Short Form-6 dimension (SF-6D) questionnaire in chronic pain. Health Qual Life Outcomes. 2013; 11:110. | Article | PubMed Abstract | PubMed FullText

61. Ostelo RW, Deyo RA, Stratford P, Waddell G, Croft P, Von Korff M, Bouter $\mathrm{LM}$ and de Vet HC. Interpreting change scores for pain and functional status in low back pain: towards international consensus regarding minimal important change. Spine (Phila Pa 1976). 2008; 33:90-4. | Article | PubMed

62. O'Sullivan P. Diagnosis and classification of chronic low back pain disorders: maladaptive movement and motor control impairments as underlying mechanism. Man Ther. 2005; 10:242-55. | Article | PubMed

63. Panjabi MM. The stabilizing system of the spine. Part I. Function, dysfunction, adaptation, and enhancement. I Spinal Disord. 1992; 5:383-9. | PubMed 
Amstel et al, Physical Therapy and Rehabilitation 2018,

64. Parreira Pdo C, Costa Lda C, Hespanhol LC, Jr., Lopes AD and Costa LO. Current evidence does not support the use of Kinesio Taping in clinical practice: a systematic review. J Physiother. 2014; 60:31-9. | Article | PubMed

65. Picavet \& verschuren. Aspecifieke lage rugklachten: omvang en gevolgen. 2016.

66. van der Roer N, Ostelo RW, Bekkering GE, van Tulder MW and de Vet HC. Minimal clinically important change for pain intensity, functional status, and general health status in patients with nonspecific low back pain Spine (Phila Pa 1976). 2006; 31:578-82. | Article | PubMed

67. Pool-Goudzwaard AL, Vleeming A, Stoeckart R, Snijders CJ and Mens JM. Insufficient lumbopelvic stability: a clinical, anatomical and biomechanical approach to 'a-specific' low back pain. Man Ther. 1998; 3:12-20. | Article | PubMed

68. Rubinstein SM, van Middelkoop M, Assendelft WJ, de Boer MR and van Tulder MW. Spinal manipulative therapy for chronic low-back pain: an update of a Cochrane review. Spine (Phila Pa 1976). 2011; 36:E825-46. | Article I PubMed

69. Salamh PA and Kolber M. The reliability, minimal detectable change and concurrent validity of a gravity-based bubble inclinometer and iphone application for measuring standing lumbar lordosis. Physiother Theory Pract. 2014; 30:62-7. | Article | PubMed

70. Saur PM, Ensink FB, Frese K, Seeger D and Hildebrandt J. Lumbar range of motion: reliability and validity of the inclinometer technique in the clinical measurement of trunk flexibility. Spine (Phila Pa 1976). 1996; 21:1332-8. | Article | PubMed

71. Shamsi M, Sarrafzadeh J, Jamshidi A, Zarabi V and Pourahmadi MR. The effect of core stability and general exercise on abdominal muscle thickness in non-specific chronic low back pain using ultrasound imaging. Physiother Theory Pract. 2016; 32:277-83. | Article | PubMed

72. Soer R, Reneman MF, Speijer BL, Coppes MH and Vroomen PC. Clinimetric properties of the EuroQol-5D in patients with chronic low back pain. Spine J. 2012; 12:1035-9. | Article | PubMed

73. Shega JW, Tiedt AD, Grant K and Dale W. Pain measurement in the National Social Life, Health, and Aging Project: presence, intensity, and location. J Gerontol B Psychol Sci Soc Sci. 2014; 69 Suppl 2:S191-7. | Article | PubMed Abstract | PubMed FullText

74. Staal J.B, Hendriks J.E.M, Heijmans M, Kiers, Lutgers-Boomsma H.A, Rutten V.G, van Tulder M.W, den Boer J, Ostelo R and Custer J.W.H. KNGFrichtlijn Lage rugpijn. 2013.

75. Thabane L, Ma J, Chu R, Cheng J, Ismaila A, Rios LP, Robson R, Thabane $\mathrm{M}$, Giangregorio $\mathrm{L}$ and Goldsmith $\mathrm{CH}$. A tutorial on pilot studies: the what, why and how. BMC Med Res Methodol. 2010; 10:1. | Article | PubMed Abstract | PubMed FullText

76. Mannion A and Troke M. A comparison of two motion analysis devices used in the measurement of lumbar spinal mobility. Clin Biomech (Bristol, Avon). 1999; 14:612-9. I Article I PubMed

77. Tozzi $P$, Bongiorno $D$ and Vitturini $C$. Fascial release effects on patients with non-specific cervical or lumbar pain. J Bodyw Mov Ther. 2011; 15:405-16. | Article | PubMed

78. Vaes P, Kerckhofs E and Beckwee D. Het gezondheidsprofiel. Anamnese en diagnose in de kinesitherapie/fysiotherapie. Standaard Uitgeverij / WPG Uitgevers België. 2011.

79. Vanti C, Bertozzi L, Gardenghi I, Turoni F, Guccione AA and Pillastrini P. Effect of taping on spinal pain and disability: systematic review and meta-analysis of randomized trials. Phys Ther. 2015; 95:493-506. | Article I PubMed

80. Vieira-Pellenz F, Oliva-Pascual-Vaca A, Rodriguez-Blanco C, HerediaRizo AM, Ricard F and Almazan-Campos G. Short-term effect of spinal manipulation on pain perception, spinal mobility, and full height recovery in male subjects with degenerative disk disease: a randomized controlled trial. Arch Phys Med Rehabil. 2014; 95:1613-9. | Article | PubMed

81. Vijayakumar P, Nagarajan M and Ramli A. Multimodal physiotherapeutic management for stage-IV osteitis pubis in a 15-year old soccer athlete: a case report. J Back Musculoskelet Rehabil. 2012; 25:225-30. | Article |
PubMed

82. Vicenzino $G$ and Twomey L. Sideflexion induced lumbar spine conjunct rotation and its influencing factors. Aust J Physiother. 1993; 39:299-306. | Article | PubMed

83. Waddell G. Evaluation of results in lumbar spine surgery. Clinical outcome measures--assessment of severity. Acta Orthop Scand Suppl. 1993; 251:134-7. I PubMed

84. Whynes DK, McCahon RA, Ravenscroft A, Hodgkinson V, Evley R and Hardman JG. Responsiveness of the EQ-5D health-related quality-of-life instrument in assessing low back pain. Value Health. 2013; 16:124-32. I Article | PubMed

\section{Citation:}

van Amstel RN, Vaes P and Malone S. The measurable impact of a protocoled multimodal physiotherapeutic intervention on the quality of life in patients with nonspecific chronic low back pain. A RCT study.

Phys Ther Rehabil. 2018; 5:2.

http://dx.doi.org/10.7243/2055-2386-5-2 